\title{
Involvement of Noradrenergic Neurotransmission in the Stress- but not Cocaine-Induced Reinstatement of Extinguished Cocaine-Induced Conditioned Place Preference in Mice: Role for $\beta-2$ Adrenergic Receptors
}

\author{
John R Mantsch*,', Andy Weyer', Oliver Vranjkovic', Chad E Beyer², David A Baker' and Holly Caretta' \\ 'Department of Biomedical Sciences, Marquette University, Milwaukee, WI, USA; ²Department of Pharmacology, University of Colorado, Aurora, \\ CO, USA
}

\begin{abstract}
The responsiveness of central noradrenergic systems to stressors and cocaine poses norepinephrine as a potential common mechanism through which drug re-exposure and stressful stimuli promote relapse. This study investigated the role of noradrenergic systems in the reinstatement of extinguished cocaine-induced conditioned place preference by cocaine and stress in male C57BL/6 mice. Cocaine( $15 \mathrm{mg} / \mathrm{kg}$, i.p.) induced conditioned place preference was extinguished by repeated exposure to the apparatus in the absence of drug and reestablished by a cocaine challenge ( $15 \mathrm{mg} / \mathrm{kg}$ ), exposure to a stressor (6-min forced swim (FS); $20-25^{\circ} \mathrm{C}$ water), or administration of the $\alpha$-2 adrenergic receptor (AR) antagonists yohimbine $(2 \mathrm{mg} / \mathrm{kg}$, i.p.) or BRL44408 (5, $10 \mathrm{mg} / \mathrm{kg}$, i.p.). To investigate the role of ARs, mice were administered the nonselective $\beta$-AR antagonist, propranolol (5, $10 \mathrm{mg} / \mathrm{kg}$, i.p.), the $\alpha-I$ AR antagonist, prazosin (I, $2 \mathrm{mg} / \mathrm{kg}$, i.p.), or the $\alpha-2$ AR agonist, clonidine $(0.03,0.3 \mathrm{mg} / \mathrm{kg}$, i.p.) before reinstatement testing. Clonidine, prazosin, and propranolol failed to block cocaine-induced reinstatement. The low $(0.03 \mathrm{mg} / \mathrm{kg})$ but not high $(0.3 \mathrm{mg} / \mathrm{kg})$ clonidine dose fully blocked FS-induced reinstatement but not reinstatement by yohimbine. Propranolol, but not prazosin, blocked reinstatement by both yohimbine and FS, suggesting the involvement of $\beta$-ARs. The $\beta$-2 AR antagonist $|\mathrm{Cl}-\mathrm{I}| 855 \mathrm{I}$ (I mg/ $\mathrm{kg}$, i.p.), but not the $\beta$ - I AR antagonist betaxolol $(10 \mathrm{mg} / \mathrm{kg}$, i.p.), also blocked FS-induced reinstatement. These findings suggest that stress-induced reinstatement requires noradrenergic signaling through $\beta-2$ ARs and that cocaine-induced reinstatement does not require AR activation, even though stimulation of central noradrenergic neurotransmission is sufficient to reinstate.

Neuropsychopharmacology (2010) 35, 2165-2178; doi: I0.1038/npp.2010.86; published online 7 July 2010
\end{abstract}

Keywords: relapse; norepinephrine; propranolol; prazosin; clonidine; beta adrenergic receptors

\section{INTRODUCTION}

The sudden reemergence of cocaine craving even after protracted periods of abstinence and the resulting relapse of drug use represent formidable obstacles to the effective management of cocaine addiction. Anecdotal reports and clinical and preclinical research have identified stress and cocaine re-exposure as likely precipitating events for drug relapse (Shaham et al, 2000a, b, 2003; Sinha, 2001; Stewart, 2003; Lu et al, 2003). Understanding the neurobiological mechanisms that contribute to the relapse of drug use in response to these stimuli should lead to the development of new and more effective approaches for treating addiction.

*Correspondence: Dr JR Mantsch, Department of Biomedical Sciences, Marquette University, Box I88I, Milwaukee, WI 5320I, USA, Tel: + I 4|4 288 2036, Fax: + I $4 \mid 4288$ 6564,

E-mail: john.mantsch@marquette.edu

Received 19 April 2010; revised 20 May 2010; accepted 20 May 2010
The preclinical study of relapse involves the use of reinstatement protocols in which the ability of various stimuli to reestablish extinguished drug-seeking behavior is examined (Shaham et al, 2003). For example, in rats and monkeys, cocaine administration or exposure to a variety of stressors will reinstate extinguished lever pressing that was previously reinforced by cocaine delivery (see Shaham et al, 2000a, b, 2003; Sinha, 2001; Stewart, 2003; Lu et al, 2003 for reviews). Relapse can also be investigated using a conditioned place preference reinstatement approach in which the ability of stimuli to reestablish extinguished preference for a previously cocaine-paired environment is examined (Tzschentke, 2007). In mice, extinguished cocaine-induced conditioned place preference can be reinstated by administration of a priming injection of cocaine (Itzhak and Martin, 2002; Orsini et al, 2008) or by exposure to stressors, including social stress (Ribeiro Do Couto et al, 2006), uncontrollable electric footshock (Redila and Chavkin, 
2008), or forced swim (Kreibich and Blendy, 2004). The use of mouse reinstatement models is important in that it should facilitate the application of genetic approaches not available in other species to further advance understanding of relapse substrates.

The responsiveness of central noradrenergic systems to both stressors (Abercrombie et al, 1988; Tanaka et al, 1991; Finlay et al, 1995) and cocaine (Reith et al, 1997; Li et al, 1996) poses norepinephrine (NE) as a potential common mechanism through which drug re-exposure and stressful environmental stimuli promote relapse. Accordingly, previous studies have suggested that antagonizing adrenergic receptors (ARs; Leri et al, 2002; Zhang and Kosten, 2005) or suppressing noradrenergic neurotransmission (Erb et al, 2000; Platt et al, 2007) can attenuate cocaine seeking, whereas augmenting adrenergic neurotransmission through antagonism of $\alpha$-2 adrenergic autoreceptors (Lee et al, 2004; Feltenstein and See, 2006; Fletcher et al, 2008; Brown et al, 2009) or blockade of reuptake (Platt et al, 2007; but see Schmidt and Pierce, 2006) can evoke cocaine seeking as measured using reinstatement protocols. Considering that in human cocaine addicts, drug craving is associated with a robust peripheral adrenergic response (Sinha et al, 2003) that seems to be augmented during early withdrawal (McDougle et al, 1994) and that repeated cocaine exposure produces long-lasting adaptations within central noradrenergic systems that may lead to enhanced noradrenergic responsiveness during stress (Belej et al, 1996; Macey et al, 2003; Baumann et al, 2004; Beveridge et al, 2005; Lanteri et al, 2008), central noradrenergic signaling may represent an important therapeutic target for the prevention of relapse (Weinshenker and Schroeder, 2007; Smith and Aston-Jones, 2008; Sofuoglu and Sewell, 2009).

This study investigated the role of noradrenergic systems in the reinstatement of extinguished cocaine-induced conditioned place preference by cocaine and stress in adult male C57 BL/6 mice. The effects of the $\alpha-1$ AR antagonist, prazosin, the $\beta$-AR antagonists, propranolol, betaxolol, and ICI-118551, and the $\alpha-2$ AR agonist, clonidine, on reinstatement by cocaine, forced swim (FS) stress, and/or the $\alpha-2$ AR antagonist, yohimbine, were examined. Our findings suggest that noradrenergic activation of $\beta-2$ ARs is selectively involved in stress-induced reinstatement.

\section{MATERIALS AND METHODS}

\section{Subjects}

A total of 250 male C57BL/6 mice (8-9 weeks old) were used (Harlan). Mice were housed singly in a temperature- and humidity-controlled, AAALAC-accredited animal facility under a 12/12 h light/dark cycle (lights on at 0700 hours) and had access to food and water at all times, except when in the experimental chambers. All procedures were carried out in accordance with the Guide for the Care and Use of Laboratory Animals as adopted and promulgated by the NIH.

\section{Drugs}

Cocaine $\mathrm{HCl}$ was acquired from the National Institute on Drug Abuse (NIDA) through the NIDA Drug Supply Program. Clonidine $\mathrm{HCl}, \pm$ propranolol $\mathrm{HCl}$, betaxolol
$\mathrm{HCl}, \mathrm{ICI}-118551 \mathrm{HCl}$, and yohimbine $\mathrm{HCl}$ were purchased from Sigma-Aldrich. BRL 44408 maleate was acquired from Tocris Bioscience. Yohimbine, prazosin, and clonidine were dissolved in sterile water. Cocaine, propranolol, betaxolol, ICI-118551, and BRL 44408 were dissolved in saline $(0.9 \%$ $\mathrm{NaCl}$ solution). All drug solutions were administered i.p. in a volume of $0.1 \mathrm{ml}$ per $20 \mathrm{~g}$ body mass.

\section{Equipment}

Behavioral testing was conducted using four ENV-3013 mouse place preference chambers from Med-Associates, Inc. The stainless steel and polyvinyl chloride chambers consisted of three distinct compartments separated by $5 \mathrm{~cm}$ wide $\times 5.9 \mathrm{~cm}$ high manual guillotine doors. The two $46.5 \times 12.7 \times 12.7 \mathrm{~cm}^{3}$ side compartments consisted of a white compartment with a $6.35 \times 6.35 \mathrm{~mm}^{2}$ stainless steel mesh floor and a black compartment with a stainless steel grid rod floor consisting of $3.2 \mathrm{~mm}$ rods spaced $7.9 \mathrm{~mm}$ apart. The side compartments were attached by a graycolored 7.2-cm-long center compartment with a smooth floor. The clear tops of the compartments were hinged to permit placement and removal of the mice. Ceiling lights were attached to each top. To balance unconditioned side preference, only the light in the black compartment was illuminated during training or testing. Automated data collection was accomplished using photobeams (six beams for the white and black test areas and two beams for the center gray area), which were evenly spaced across the length of the chamber and interfaced with a computer containing Med-PC software. Using this automated photobeam system, entry into a side compartment was defined as consecutive breaks of the first two photocell beams in that compartment located adjacent to the door separating that compartment from the center compartment. Exiting of a side compartment (and entry into the center compartment) was indicated by occlusion of the beams in the center compartment.

\section{Cocaine-Induced Conditioned Place Preference}

Cocaine-induced conditioned place preference was established using a design in which one of the side compartments was randomly designated as the cocaine compartment and the other as the saline compartment. On the first day of the procedure, mice were placed into the center compartment of the chamber and provided free access to both side compartments for $30 \mathrm{~min}$ in the absence of saline or cocaine pretreatment to determine preconditioning preference. During the 8-day conditioning phase of the experiment, mice received cocaine $(15 \mathrm{mg} / \mathrm{kg}$, i.p.) and saline injections on alternating days, after which they were confined to the randomly designated treatment-appropriate compartment for $30 \mathrm{~min}$. After the final conditioning session, mice were tested for the expression of cocaine-induced conditioned place preference by once again placing them into the center compartment of the chamber and providing them with free access to the side compartments for $30 \mathrm{~min}$. Conditioned place preference was defined as the change in time spent (seconds) within the cocaine-paired compartment after conditioning when compared with the initial preconditioning session. The $15 \mathrm{mg} / \mathrm{kg}$ cocaine dose was selected on the 

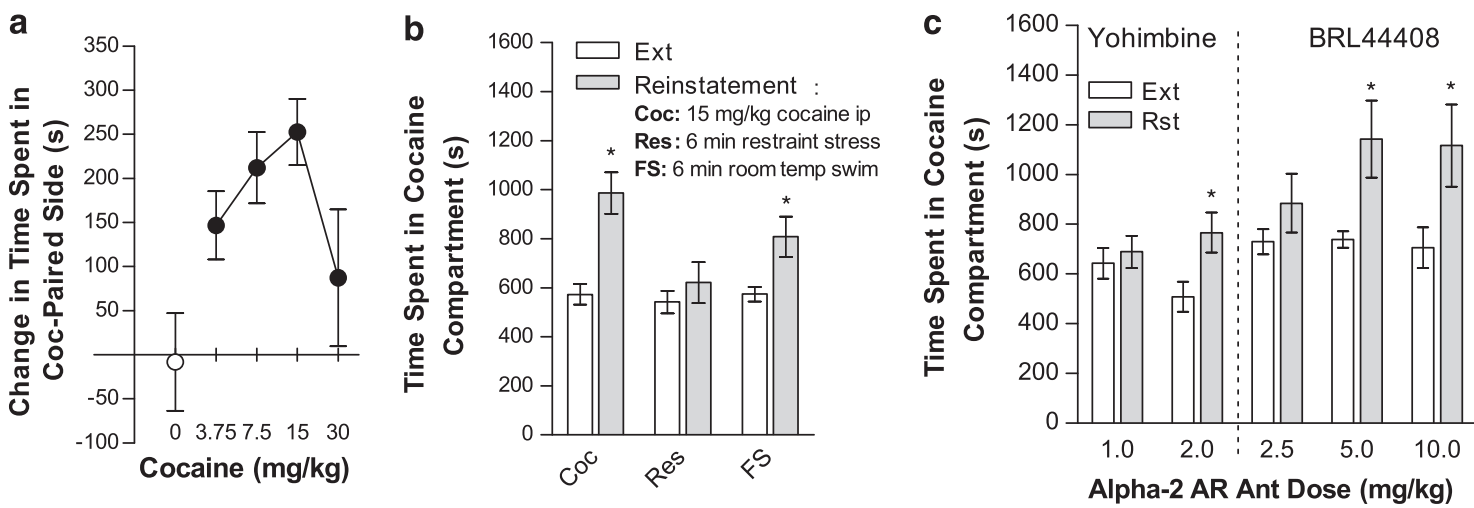

Figure I Induction and reinstatement of cocaine-induced conditioned place preference. Cocaine dose-dependently induced conditioned place preference with peak effects at the $15 \mathrm{mg} / \mathrm{kg}$ (i.p.) dose. Data in (a) represent the mean change in time spent (sec \pm SE) in the cocaine-paired compartment between the pre- and post-conditioning test sessions in mice that were conditioned with various cocaine doses (0-30 mg/kg, i.p.; $n=10-20 / g r o u p)$. On the basis of these data, the $15 \mathrm{mg} / \mathrm{kg}$ cocaine dose was selected as the conditioning and reinstatement dose for each experiment. (b and c) Show the reinstatement of extinguished cocaine-induced conditioned place preference by cocaine (Coc; $10 \mathrm{mg} / \mathrm{kg}$, i.p.; $n=23 ; b)$, physical restraint (Res; $n=26 ; b)$, forced swim (FS; $n=16 ; b$ ), and by the $\alpha-2$ AR antagonists yohimbine (Yoh; I and $2 \mathrm{mg} / \mathrm{kg}$, i.p.; $n=23 ; \mathrm{c}$ ) and BRL 44408 (BRL; 2.5, 5, and I0 mg/kg, i.p.; $n=6-8 ; c)$. Data represent the time spent in the Coc compartment (sec \pm SE) during the 30-min reinstatement (Rst) session (filled bars) or during the preceding extinction session (open bars). Coc, FS, $2 \mathrm{mg} / \mathrm{kg}$ Yoh, and 5 and $10 \mathrm{mg} / \mathrm{kg}$ BRL but not Res, I mg/kg Yoh or $2.5 \mathrm{mg} / \mathrm{kg}$ BRL, produced significant reinstatement $(* p<0.05$ vs Ext).

basis of results of a preliminary study in which the ability of various cocaine doses to produce place preference was examined (Figure 1a).

\section{Extinction}

After conditioning, daily extinction training was conducted. During the extinction sessions, mice were placed into the center compartment and once again provided free access to the side compartments for $30 \mathrm{~min}$. Mice underwent daily extinction training until the preference for the cocainepaired compartment during the session (ie, change in time spent in the cocaine side relative to preconditioning values) was reduced by at least $50 \%$ compared with the postconditioning test session, at which time reinstatement testing was conducted.

\section{Reinstatement Testing}

The reinstatement sessions were identical to the extinction sessions, except that mice received exposure to stressors and/or drug injections before the session. Reinstatement was defined according to the time spent in the compartment previously paired with cocaine. Mice were tested more than once for reinstatement. Generally, each mouse was tested with each of the three reinstating stimuli (cocaine, forced swim (FS), and yohimbine) alone and in combination with one drug pretreatment and its respective vehicle in counterbalanced order to avoid potential sequence effects. Reinstatement sessions were separated by additional extinction sessions. Mice were required to reach the extinction criterion once again before the next reinstatement test was conducted. Initially, separate groups of mice were tested for the ability of various stressors and drugs, when delivered in the absence of pretreatments, to produce reinstatement.

\section{Drug-Induced Reinstatement}

Cocaine- and yohimbine-induced reinstatement testing was conducted by injecting mice with cocaine $(15 \mathrm{mg} / \mathrm{kg}$, i.p.) or yohimbine ( 1 or $2 \mathrm{mg} / \mathrm{kg}$, i.p.) either alone or $30 \mathrm{~min}$ after pretreatment with clonidine $(0.03$ and $0.3 \mathrm{mg} / \mathrm{kg})$, propranolol (5 and $10 \mathrm{mg} / \mathrm{kg}$ ), prazosin ( 1 and $2 \mathrm{mg} / \mathrm{kg}$ ), betaxolol $(10 \mathrm{mg} / \mathrm{kg})$, or ICI-118551 $(10 \mathrm{mg} / \mathrm{kg})$, or their respective vehicles and placing mice into the center compartment 5 min later with free access to both sides of the compartment for $30 \mathrm{~min}$. Reinstatement by clonidine, propranolol, prazosin, betaxolol, and ICI-118551 alone was also tested after administration $30 \mathrm{~min}$ before the reinstatement session, a time point that matched the pretreatment time when these drugs were administered before cocaine, yohimbine, or FS during testing. To confirm that antagonism of $\alpha-2$ AR by yohimbine may have contributed to reinstatement, a separate group of mice was tested for reinstatement in response to the highly selective $\alpha-2$ AR antagonist, BRL 44408 (2.5, 5, and $10 \mathrm{mg} / \mathrm{kg}$, i.p.).

\section{Stress-Induced Reinstatement}

FS-induced reinstatement was examined by placing mice into a $30 \mathrm{~cm}$ high $\times 20 \mathrm{~cm}$ deep cylindrical polypropylene container filled with water $\left(20-25^{\circ} \mathrm{C}\right)$ for $6 \mathrm{~min}, 30 \mathrm{~min}$ after pretreatment with clonidine $(0.03$ and $0.3 \mathrm{mg} / \mathrm{kg})$, propranolol ( 5 and $10 \mathrm{mg} / \mathrm{kg}$ ), prazosin ( 1 and $2 \mathrm{mg} / \mathrm{kg}$ ), or their respective vehicles. After FS, mice were placed back into their home cages for 3-4 min before introducing them into the center compartment of the place conditioning chamber with free access to both of the side compartments for reinstatement testing, as described above. Initially, some mice were also tested for reinstatement following $5 \mathrm{~min}$ of physical restraint using a mouse restrainer cone $(5.7 \mathrm{~cm}$ diameter tapered to $1.2 \mathrm{~cm}$ diameter; $11 \mathrm{~cm}$ length). These mice were also returned to their home cages after restraint for 3-4 min before placement into the apparatus for reinstatement testing. As propranolol blocked FS-induced reinstatement, we also tested the mice for the effects of the selective $\beta-1 \mathrm{AR}$ antagonist, betaxolol $(10 \mathrm{mg} / \mathrm{kg}$, i.p.), and the selective $\beta-2$ AR antagonist, ICI-118551 (1 mg/kg, i.p.), on reinstatement after FS. 


\section{Locomotor Testing}

To assist with dose selection, the effects of various doses of clonidine, prazosin, and propranolol on locomotor activity were tested in 26 mice using an automated AccuScan activity system (AccuScan Instruments, Inc., Columbus, $\mathrm{OH}$ ) consisting of a frame containing photocells (eight per cage), in which clear Plexiglas $29.5 \mathrm{~cm} \mathrm{long} \times 19 \mathrm{~cm}$ wide $\times 12.7 \mathrm{~cm}$ high cages were placed. Activity was measured as total photobeam breaks. During the week before the locomotor testing, mice were habituated to the test environment during two 2-h sessions. On the test day, mice were placed into the chambers for $2 \mathrm{~h}$ before the drug administration, after which was measured over a 2 -h period. The effects of clonidine $(0,0.03,0.3$, and $1 \mathrm{mg} / \mathrm{kg}$, i.p.), prazosin $(0,1,2$, and $4 \mathrm{mg} / \mathrm{kg}$, i.p.), and propranolol $(0,5$, 10 , and $20 \mathrm{mg} / \mathrm{kg}$, i.p.) were tested in separate groups of mice. Only doses that failed to produce statistically significant reductions in activity were tested for effects on reinstatement.

\section{Statistical Analyses}

Place preference during testing, extinction, and reinstatement was defined as the time spent (sec) in the designated cocaine compartment. The abilities of individual stimuli to reinstate place preference in the absence of drug pretreatments were examined statistically using two-tailed Student's $t$-tests comparing the time spent in the cocaine compartment during the previous extinction session with that during the reinstatement session. The significance of the effects of drug pretreatments on reinstatement by each of the stimuli was determined using two-way repeated measures reinstatement $\times$ drug pretreatment ANOVA followed by post-hoc testing using two-tailed Student's $t$-tests. The significance of dose-related drug effects on locomotor activity was determined using one-way (drug dose) ANOVA followed by post-hoc testing using the Dunnett's test. For all analyses, significance was defined as $p<0.05$.

\section{RESULTS}

\section{Establishment and Reinstatement of Cocaine-Induced Conditioned Place Preference}

Dose-response analysis showed that the $15 \mathrm{mg} / \mathrm{kg}$ cocaine dose was optimal for producing conditioned place preference ( $n=10-20$ mice per cocaine/veh dose; Figure 1a). Although not shown, significant cocaine-induced conditioned place preference, defined as an increase in time spent in the cocaine-paired compartment, was observed in each of the experiments in which reinstatement was later examined ( $p<0.05$ for each experiment). The overall average number of extinction sessions before the first reinstatement test session was 8.757. Overall, 28 mice (out of 224 that underwent conditioning) were not tested for reinstatement, because they either did not show cocaine-induced conditioned place preference or failed to reach the extinction criterion.

The ability of cocaine and stress to reinstate extinguished cocaine-induced place preference is shown in Figure $1 \mathrm{~b}$. Administration of $15 \mathrm{mg} / \mathrm{kg}$ cocaine $\left(t_{22}=4.949 ; n=23\right)$ or
FS $\left(t_{15}=3.128 ; n=16\right)$, but not restraint $(n=26)$, significantly increased the time spent in the cocaine compartment following extinction $(p<0.01)$.

To determine whether stimulating central noradrenergic neurotransmission through antagonism of $\alpha-2$ AR is sufficient to induce reinstatement, mice were tested for the ability of yohimbine and the more selective $\alpha-2 \mathrm{~A}$ AR antagonist, BRL 44408, to reinstate extinguished place preference (Figure 1c). For yohimbine, a two-way reinstatement condition (repeated measure) $\times$ yohimbine dose (1 vs $2 \mathrm{mg} / \mathrm{kg}$ ) ANOVA showed a significant overall effect of reinstatement condition $\left(\mathrm{F}_{1,33}=5.252 ; p<0.05\right)$ but not yohimbine dose, and a significant reinstatement condition $\times$ dose interaction $\left(\mathrm{F}_{1,33}=4.089 ; p=0.05\right)$. The $2 \mathrm{mg} / \mathrm{kg}$ $\left(t_{22}=3.371 ; n=23\right)$, but not $1 \mathrm{mg} / \mathrm{kg}(n=23)$, yohimbine dose produced significant reinstatement $(p<0.01)$. Although yohimbine can increase central noradrenergic neurotransmission through antagonism of $\alpha-2$ ARs, it also binds to several other receptors, including the $5-\mathrm{HT}_{1 \mathrm{~A}}$ receptor, where it functions as an antagonist and may produce effects independently of the noradrenergic system (Sanger and Schoemaker, 1992; Winter and Rabin, 1992). To confirm that $\alpha-2$ AR antagonism is sufficient to induce reinstatement, we also tested some mice for reinstatement after administration of the selective $\alpha-2 \mathrm{~A}$ AR antagonist BRL 44408, which has a 50-fold higher affinity for $\alpha-2 \mathrm{~A} \mathrm{AR}$ relative to $5-\mathrm{HT}_{1 \mathrm{~A}}$ receptors (Dwyer et al, 2010). A two-way repeated-measures reinstatement condition $\times$ BRL 44408 dose $(2.5,5.0,10.0 \mathrm{mg} / \mathrm{kg})$ ANOVA showed a significant overall effect of reinstatement condition $\left(\mathrm{F}_{1,6}=13.557\right.$; $p=0.01$ ) but not BRL 44408 dose, and a significant reinstatement condition $\times$ dose interaction $\left(\mathrm{F}_{2,12}=4.222\right.$; $p<0.05)$. Similar to yohimbine, BRL 44408 dose-dependently reinstated, with significant effects observed at the 5 $\left(t_{6}=2.776 ; p<0.05\right)$ and $10\left(t_{7}=2.538 ; p<0.05\right)$, but not at the $2.5 \mathrm{mg} / \mathrm{kg}$ BRL 44408 doses.

\section{Locomotor Testing}

Propranolol, prazosin, and clonidine each produced dosedependent reductions in locomotor activity (Figure 2). Oneway prazosin dose ANOVA examining the effects of 1, 2, and $4 \mathrm{mg} / \mathrm{kg}$ prazosin on locomotor activity showed a significant overall effect $\left(\mathrm{F}_{1,36}=3.300 ; p<0.05\right)$. Post-hoc testing using the Dunnett's $t$-test showed that the $4 \mathrm{mg} / \mathrm{kg}$ dose, but not the other prazosin doses, significantly reduced locomotor activity compared with vehicle-treated controls $(p<0.01)$. Similarly, one-way propranolol dose ANOVA examining the effects of 5,10 , and $20 \mathrm{mg} / \mathrm{kg}$ propranolol on locomotor activity showed a significant overall effect $\left(\mathrm{F}_{1,36}=3.244 ; p<0.05\right)$. Post-hoc testing using the Dunnett's $t$-test showed that the $20 \mathrm{mg} / \mathrm{kg}$ dose, but not the other propranolol doses, significantly reduced locomotor activity compared with vehicle-treated controls $(p<0.05)$. One-way clonidine dose ANOVA examining the effects of $0.03,0.3$, and $1 \mathrm{mg} / \mathrm{kg}$ clonidine on locomotor activity failed to show a significant overall effect of clonidine, despite a nearsignificant trend $\left(\mathrm{F}_{3,33}=2.693 ; p=0.06\right)$. Post-hoc testing using the Dunnett's $t$-test showed that the $1 \mathrm{mg} / \mathrm{kg}$ dose, but not the other clonidine doses, significantly reduced locomotor activity compared with vehicle-treated controls $(p<0.05)$. As $4 \mathrm{mg} / \mathrm{kg}$ prazosin, $20 \mathrm{mg} / \mathrm{kg}$ propranolol, and 

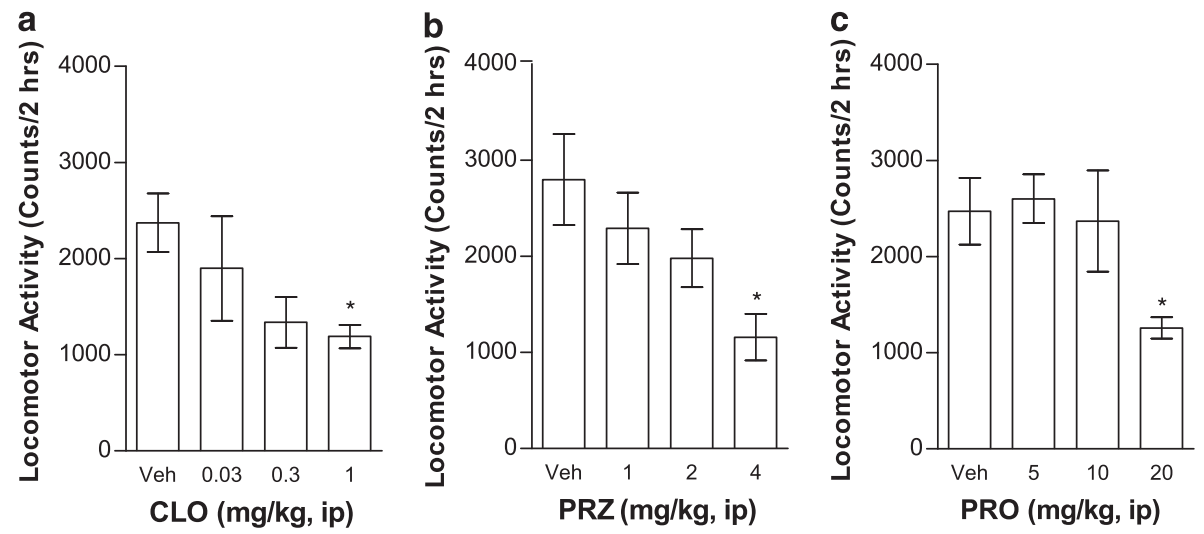

Figure 2 Effects of clonidine (CLO; a), prazosin (PRZ; b), and propranolol (PRO; c) or their respective vehicles (Veh) on locomotor activity. To facilitate dose selection, mice ( $n=6-10$ per dose) were tested for the effects of CLO, PRZ, and PRO on locomotor activity. Data represent locomotor counts (total photobeam breaks) measured during a 2-h session that immediately followed drug administration. Each drug dose-dependently attenuated locomotor activity ( $P<0.05$; significant reduction vs Veh).

Table I Effects of Prazosin (Prz), Propranolol (Pro), Clonidine (Clo), Betaxolol (Bet), and ICl-I I855I (ICl) on Time Spent in the Cocaine Compartment Following the Extinction of CocaineInduced Conditioned Place Preference $(n=8-14$ per drug)

\begin{tabular}{lcl}
\hline Drug (dose) & Ext & Reinstatement \\
\hline Prz $(1.0 \mathrm{mg} / \mathrm{kg})$ & $614.84( \pm 47.8 \mathrm{I})$ & $592.86( \pm 54.40)$ \\
$\operatorname{Prz}(2.0 \mathrm{mg} / \mathrm{kg})$ & $583.29( \pm 24.59)$ & $673.34( \pm 85.93)$ \\
Pro $(5.0 \mathrm{mg} / \mathrm{kg})$ & $617.53( \pm 58.3 \mathrm{I})$ & $582.35( \pm 85.03)$ \\
Pro $(10.0 \mathrm{mg} / \mathrm{kg})$ & $640.60( \pm 80.72)$ & $602.77( \pm 91.6 \mathrm{I})$ \\
Clo $(0.03 \mathrm{mg} / \mathrm{kg})$ & $583.55( \pm 70.28)$ & $613.27( \pm 75.18)$ \\
Clo $(0.3 \mathrm{mg} / \mathrm{kg})$ & $595.80( \pm 34.8 \mathrm{I})$ & $913.1 \mathrm{I}( \pm \mid 31.27) *$ \\
Bet $(10.0 \mathrm{mg} / \mathrm{kg})$ & $668.42( \pm 43.1 \mathrm{I})$ & $659.47( \pm 63.0 \mathrm{I})$ \\
$\mathrm{ICl}(1.0 \mathrm{mg} / \mathrm{kg})$ & $622.45( \pm 36.0 \mathrm{I})$ & $607.18( \pm 87.56)$ \\
\hline
\end{tabular}

Data represent the time spent in the cocaine compartment (sec \pm SE) during the reinstatement session after drug administration (reinstatement) or during the preceding extinction session (Ext). Only the high (ie, $0.3 \mathrm{mg} / \mathrm{kg}$ ) clonidine dose reinstated extinguished conditioned place preference ( $p<<0.05$ vs Ext; $n=13$ ).

$1 \mathrm{mg} / \mathrm{kg}$ clonidine produced significant reductions in locomotor activity, we chose not to test the effects of these doses on reinstatement.

\section{Reinstatement by Prazosin, Propranolol, Clonidine, Betaxolol, and ICI-118551}

To ensure that the $\alpha-1$ AR antagonist prazosin, the $\beta$-AR antagonists propranolol, betaxolol and ICI-118551, and the $\alpha-2$ AR agonist clonidine did not, by themselves, alter preference for the cocaine compartment after extinction, we initially examined the ability of these drugs, when administered alone, to reinstate extinguished conditioned place preference at the doses to be used (Table 1). Whereas prazosin $(1 \mathrm{mg} / \mathrm{kg} ; n=12$ or $2 \mathrm{mg} / \mathrm{kg} ; n=14)$, propranolol $(5 \mathrm{mg} / \mathrm{kg} ; n=8$ or $10 \mathrm{mg} / \mathrm{kg} ; n=10)$, betaxolol $(10 \mathrm{mg} / \mathrm{kg}$; $n=12)$, or ICI-118551 $(5 \mathrm{mg} / \mathrm{kg} ; n=12)$ failed to alter the amount of time spent in the cocaine-paired compartment after extinction, clonidine, at the higher $(0.3 \mathrm{mg} / \mathrm{kg}$; $\left.t_{12}=2.491, p<0.05 ; n=13\right)$ but at not the lower $(0.03 \mathrm{mg} /$ $\mathrm{kg} ; n=13)$ dose, produced significant reinstatement $(p<0.05)$.

\section{Effects of Clonidine on Reinstatement}

As augmentation of central noradrenergic neurotransmission by administration of yohimbine or the selective $\alpha-2 \mathrm{~A}$ AR antagonist, BRL-44408, induced reinstatement, we hypothesized that noradrenergic neurotransmission during stress or after cocaine exposure may contribute to stressand cocaine-induced drug seeking. To test this hypothesis, mice were tested for FS- or cocaine-induced reinstatement after administration of clonidine, an $\alpha-2$ AR agonist that suppresses evoked increases in NE (Florin et al, 1994; Tjurmina et al, 1999) presumably by the activation of inhibitory autoreceptors on noradrenergic nerve terminals.

\section{Forced Swim}

The effects of clonidine ( 0.03 and $0.3 \mathrm{mg} / \mathrm{kg}$, i.p.) on FSinduced reinstatement are shown in Figure 3. Clonidine suppressed FS-induced reinstatement, but only at the $0.03 \mathrm{mg} / \mathrm{kg}$ dose. A total of 27 mice were used to test for the effects of $0.03 \mathrm{mg} / \mathrm{kg}$ clonidine dose on FS-induced reinstatement (Figure 3a). Two-way repeated-measures FS $\times$ clonidine treatment condition ANOVA showed a significant overall effect of FS $\left(\mathrm{F}_{1,26}=6.199 ; p<0.05\right)$ but not clonidine treatment condition on time spent in the cocaine compartment and a significant clonidine $\times$ FS interaction $\left(\mathrm{F}_{1,26}=12.264 ; p<0.01\right)$. Post-hoc examination of reinstatement in each group revealed that FS significantly reinstated place preference in vehicle-treated but not clonidine-treated mice $\left(t_{26}=3.230 ; p<0.05\right)$ and that time spent in the cocaine compartment was significantly reduced by clonidine after FS $\left(t_{26}=3.012 ; p<0.05\right)$. Nine mice were used to test the effects of the $0.3 \mathrm{mg} / \mathrm{kg}$ clonidine dose on FS-induced reinstatement (Figure $3 \mathrm{~b}$ ). In contrast to the $0.03 \mathrm{mg} / \mathrm{kg}$ clonidine dose, $0.3 \mathrm{mg} / \mathrm{kg}$ clonidine failed to block FS-induced reinstatement. Two-way repeated measures FS $\times$ clonidine treatment condition ANOVA showed a significant overall effect of FS $\left(\mathrm{F}_{1,8}=6.122 ; p<0.05\right)$, but not of clonidine and no FS $\times$ clonidine interaction.

\section{Cocaine}

The effects of clonidine ( 0.03 or $0.3 \mathrm{mg} / \mathrm{kg}$, i.p.) on cocaineinduced reinstatement are shown in Figure 4. Neither 

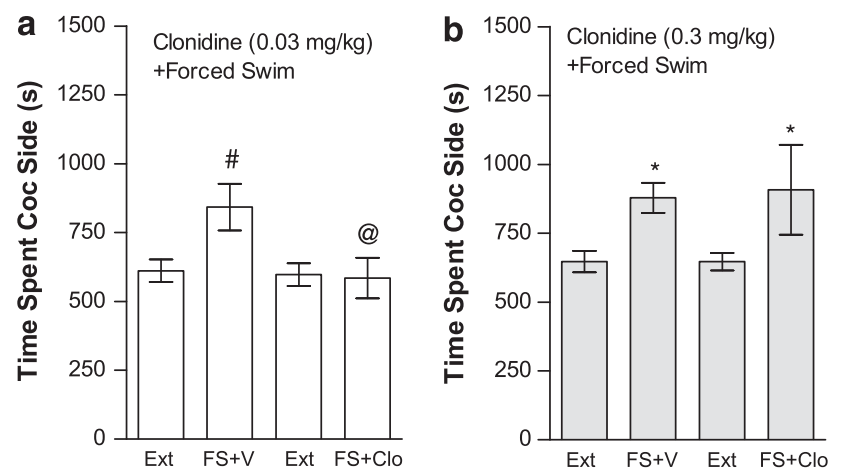

Figure 3 The The $\alpha-2$ AR agonist clonidine dose-dependently blocks stress-induced reinstatement. Data represent the time spent in the cocaine (Coc) compartment (sec $\pm \mathrm{SE}$ ) during the final extinction session prior to reinstatement testing (Ext) and during reinstatement testing after forced swim (FS) after pretreatment with vehicle (V) or clonidine (Clo). A significant interaction between FS and Clo was found in mice tested at the $0.03 \mathrm{mg} / \mathrm{kg}$ (i.p.) Clo dose (a; $n=27 ; p>0.05$ ). Post-hoc testing showed that FS increased time spent in the Coc compartment after treatment with $\vee\left({ }^{\#} p<0.05\right)$ but not $0.03 \mathrm{mg} / \mathrm{kg}$ Clo. Further, time spent in the Coc compartment was significantly reduced after $0.03 \mathrm{mg} / \mathrm{kg}$ Clo compared with $\vee\left({ }^{@} p<0.05\right)$. The effect of $0.3 \mathrm{mg} / \mathrm{kg}$ (i.p.) Clo $(n=9)$ on FS-induced reinstatement is shown in $b$. A significant main effect of FS $(* p<0.05)$ but no $\mathrm{FS} \times \mathrm{Clo}$ interaction was found at this dose.
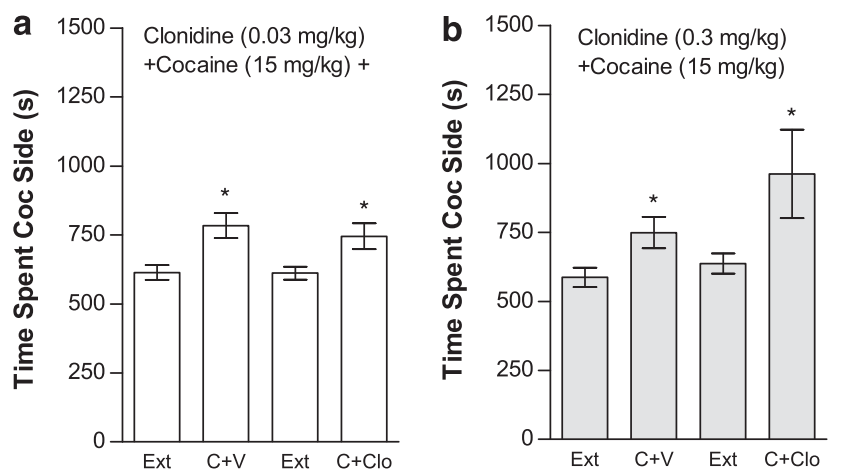

Figure 4 The $\alpha-2$ AR agonist clonidine does not block cocaine-induced reinstatement. Data represent the time spent in the cocaine (Coc) compartment (sec $\pm \mathrm{SE}$ ) during the final extinction session before reinstatement testing (Ext) and during reinstatement testing after administration of cocaine (C; $15 \mathrm{mg} / \mathrm{kg}$, i.p.) after pretreatment with vehicle $(\mathrm{V})$ or $0.03 \mathrm{mg} / \mathrm{kg}$ clonidine (i.p.) $(\mathrm{Clo} ; n=25 ; \mathrm{a})$ or with $\mathrm{V}$ or $0.3 \mathrm{mg} / \mathrm{kg} \mathrm{Clo}$ $(n=13$; b). In both cases, significant main effects of $C(* p<0.05)$ but no significant $\mathrm{C} \times \mathrm{Clo}$ interactions were found.

clonidine dose blocked cocaine-induced reinstatement. The effect of $0.03 \mathrm{mg} / \mathrm{kg}$ clonidine was tested in 25 mice (Figure 4a). Two-way cocaine $\times 0.03 \mathrm{mg} / \mathrm{kg}$ clonidine treatment condition ANOVA showed a significant overall effect of cocaine priming $\left(\mathrm{F}_{1,24}=22.807 ; p<0.001\right)$ on time spent in the cocaine compartment. However, no significant main effect of clonidine treatment condition or interaction between clonidine treatment and cocaine-induced reinstatement was found. In all, 13 mice were tested for the effect of a 10 -fold higher clonidine dose $(0.3 \mathrm{mg} / \mathrm{kg}$, i.p.) on cocaineinduced reinstatement (Figure $4 \mathrm{~b}$ ). Not only did this higher clonidine dose fail to block cocaine-induced reinstatement, but it also tended to augment reinstatement in response to cocaine. Similar to the lower clonidine dose, two-way cocaine $\times$ clonidine treatment condition ANOVA showed a significant overall effect of cocaine priming $\left(F_{1,12}=9.319\right.$; $p=0.01$ ) on time spent in the cocaine compartment, with no main effect of clonidine treatment condition and no interaction between clonidine treatment and cocaineinduced reinstatement.

\section{Yohimbine}

The effects of clonidine on yohimbine-induced reinstatement are shown in Figure 5. As yohimbine likely reinstates extinguished cocaine seeking by blockade of $\alpha-2$ ARs, we anticipated that yohimbine-induced reinstatement would be attenuated by clonidine. Surprisingly, neither the low (ie, $0.03 \mathrm{mg} / \mathrm{kg}$ ) nor the high (ie, $0.3 \mathrm{mg} / \mathrm{kg}$ ) clonidine dose blocked yohimbine-induced reinstatement. A total of 40 mice were tested for the effects of $0.03 \mathrm{mg} / \mathrm{kg}$ clonidine on yohimbine-induced reinstatement (Figure 5a). Two-way repeated-measures ANOVA showed a significant overall effect of yohimbine on time spent in the cocaine compartment $\left(F_{1,39}=13.306\right)$ but failed to show a significant main effect of $0.03 \mathrm{mg} / \mathrm{kg}$ clonidine treatment condition or a significant interaction between clonidine treatment and yohimbine-induced reinstatement. We reasoned that our inability to fully block yohimbine-induced reinstatement with $0.03 \mathrm{mg} / \mathrm{kg}$ clonidine may have been dose-related because of the competition for the same receptor site. However, when we tested mice with $0.3 \mathrm{mg} / \mathrm{kg}$ clonidine $(n=38)$, there was little evidence for a reduction of yohimbine-induced reinstatement at this dose (Figure $5 \mathrm{~b}$ ). Two-way repeated-measures yohimbine-induced reinstatement $\times 0.3 \mathrm{mg} / \mathrm{kg}$ clonidine treatment condition ANOVA showed a significant overall effect of yohimbine $\left(\mathrm{F}_{1,37}=8.507 ; p<0.01\right)$, but no overall effect of clonidine pretreatment and no yohimbine reinstatement $\times$ clonidine pretreatment interaction.

\section{Effects of Prazosin on Reinstatement}

To examine the role of $\alpha-1$ ARs in reinstatement by various stimuli, mice were pretreated with the $\alpha-1$ AR antagonist prazosin ( 2 and $4 \mathrm{mg} / \mathrm{kg}$ ) before FS or administration of cocaine or yohimbine. In all cases, prazosin failed to alter reinstatement.

\section{Forced Swim}

The effects of prazosin ( 1 or $2 \mathrm{mg} / \mathrm{kg}$, i.p.) on FS-induced reinstatement are shown in Figure 6. Neither prazosin dose blocked reinstatement after FS. The effect of $1 \mathrm{mg} / \mathrm{kg}$ prazosin was tested in five mice (Figure 6a). Two-way repeated-measures $\mathrm{FS} \times 1 \mathrm{mg} / \mathrm{kg}$ prazosin treatment condition ANOVA showed a significant overall effect of FS $\left(\mathrm{F}_{1,4}=12.251 ; p<0.05\right)$ on time spent in the cocaine compartment. However, no significant main effect of prazosin treatment condition or interaction between prazosin and FS-induced reinstatement was found. In all 14 mice were tested for the effect of $2 \mathrm{mg} / \mathrm{kg}$ prazosin on FSinduced reinstatement (Figure 6b). Similar to the lower prazosin dose, two-way repeated-measures $\mathrm{FS} \times 2 \mathrm{mg} / \mathrm{kg}$ prazosin treatment condition ANOVA showed a significant overall effect of $\mathrm{FS}\left(\mathrm{F}_{1,13}=5.368 ; p<0.05\right)$ on time spent in 

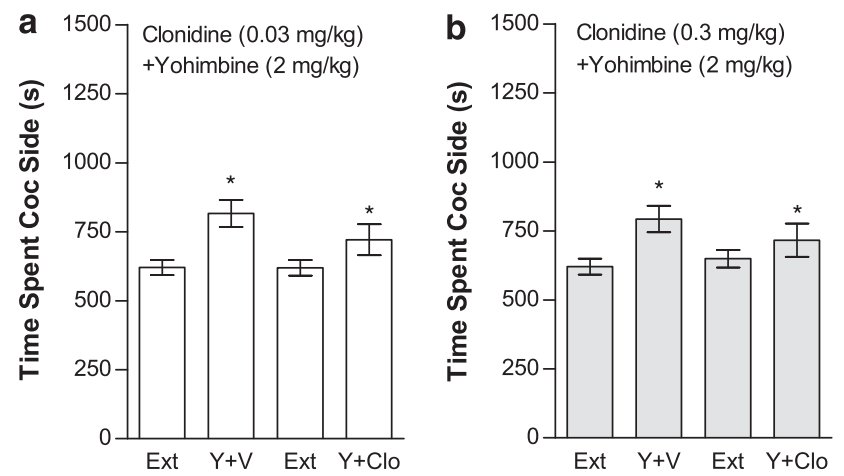

Figure 5 The $\alpha-2$ AR agonist clonidine does not block yohimbineinduced reinstatement. Data represent the time spent in the cocaine (Coc) compartment $(\mathrm{sec} \pm \mathrm{SE})$ during the final extinction session prior to reinstatement testing (Ext) and during reinstatement testing after administration of yohimbine (Y; $2 \mathrm{mg} / \mathrm{kg}$, i.p.) after pretreatment with vehicle $(V)$ or $0.03 \mathrm{mg} / \mathrm{kg}$ clonidine (i.p.) $(\mathrm{Clo} ; n=40$; a) or with $V$ or $0.3 \mathrm{mg} / \mathrm{kg}$ Clo $(n=38 ; b)$. In both cases, significant main effects of $Y$ $(* p<0.05)$ but no significant $Y \times C$ Clo interactions were found.
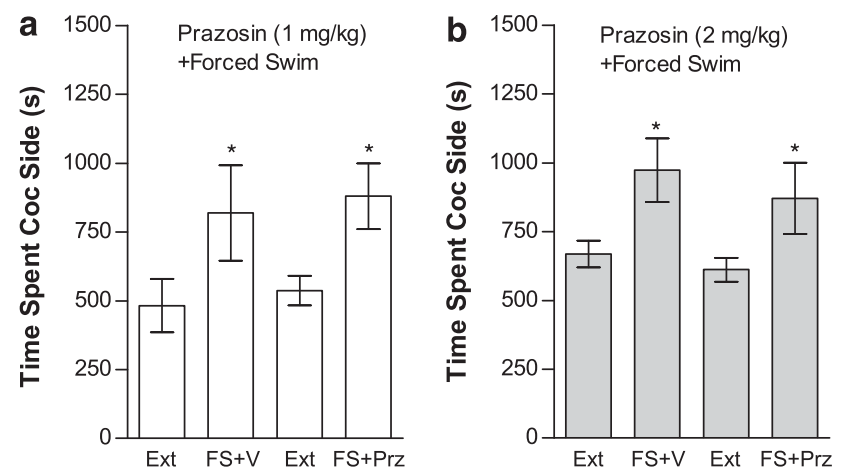

Figure 6 The selective $\alpha-\mid$ AR antagonist prazosin does not block stress-induced reinstatement. Data represent the time spent in the cocaine (Coc) compartment (sec $\pm \mathrm{SE}$ ) during the final extinction session prior to reinstatement testing (Ext) and during reinstatement testing after forced swim (FS) after pretreatment with vehicle $(\mathrm{V})$ or $1 \mathrm{mg} / \mathrm{kg}$ (i.p.) prazosin (Prz; $n=5 ; a)$ or pretreatment with $V$ or $2 \mathrm{mg} / \mathrm{kg}$ (i.p.) Prz $(n=14 ; \mathrm{b})$. In both cases, significant main effects of FS $(* p<0.05)$ but no FS $\times$ Prz interactions were found.

the cocaine compartment, with no main effect of prazosin treatment condition and no interaction between prazosin and FS.

\section{Cocaine}

The effects of prazosin on cocaine-induced reinstatement are shown in Figure 7. Neither prazosin dose blocked cocaine-induced reinstatement. The effect of $1 \mathrm{mg} / \mathrm{kg}$ prazosin was tested in a total of 11 mice (Figure 7a). Twoway cocaine $\times 1 \mathrm{mg} / \mathrm{kg}$ prazosin treatment condition ANOVA showed a significant overall effect of cocaine $\left(\mathrm{F}_{1,10}=9.000 ; p<0.05\right)$ on time spent in the cocaine compartment. However, no significant main effect of prazosin treatment condition or interaction between prazosin and cocaine-induced reinstatement was found. A total of 13 mice were tested for the effect of $2 \mathrm{mg} / \mathrm{kg}$ prazosin on cocaine-induced reinstatement (Figure $7 \mathrm{~b}$ ).
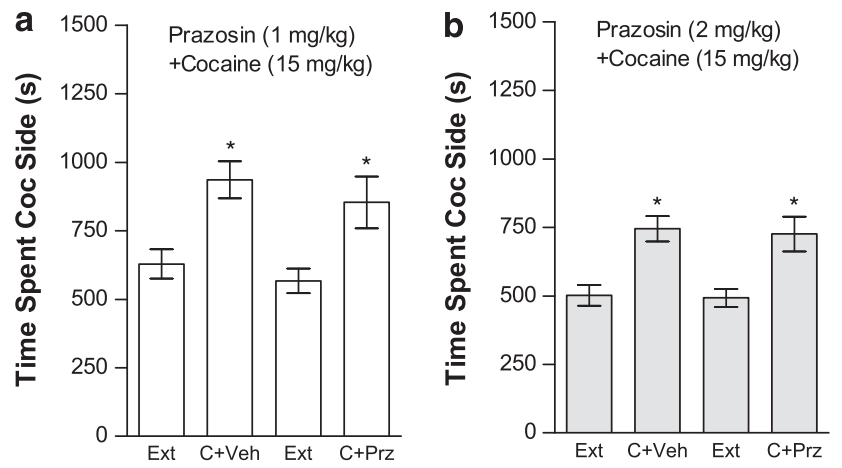

Figure 7 The selective $\alpha-\mid$ AR antagonist prazosin does not block cocaine-induced reinstatement. Data represent the time spent in the cocaine (Coc) compartment (sec $\pm \mathrm{SE}$ ) during the final extinction session before reinstatement testing (Ext) and during reinstatement testing after administration of cocaine (C; $15 \mathrm{mg} / \mathrm{kg}$, i.p.) after pretreatment with vehicle $(\mathrm{V})$ or $\mathrm{I} \mathrm{mg} / \mathrm{kg}$ (i.p.) prazosin (Prz; $n=1 \mathrm{I}$; a) or pretreatment with $\mathrm{V}$ or $2 \mathrm{mg} / \mathrm{kg}$ (i.p.) $\operatorname{Prz}(n=13 ;$ b). In both cases, significant main effects of $C$ $\left({ }^{*} p<0.05\right)$ but no $C \times \operatorname{Prz}$ interactions were found.

Similar to the lower prazosin dose, two-way cocaine $\times 2 \mathrm{mg} / \mathrm{kg}$ prazosin treatment condition ANOVA showed a significant overall effect of cocaine $\left(\mathrm{F}_{1,12}=17.241 ; p<0.01\right)$ on time spent in the cocaine compartment, with no main effect of prazosin treatment condition and no interaction between prazosin treatment and cocaine-induced reinstatement.

\section{Yohimbine}

The effects of prazosin on cocaine-induced reinstatement are shown in Figure 8. Neither prazosin dose blocked yohimbine-induced reinstatement. The effect of $1 \mathrm{mg} / \mathrm{kg}$ prazosin was tested in six mice (Figure 8a). Two-way repeated measures yohimbine $\times 1 \mathrm{mg} / \mathrm{kg}$ prazosin treatment condition ANOVA showed a significant overall effect of yohimbine $\left(\mathrm{F}_{1,5}=13.114 ; p<0.05\right)$ on time spent in the cocaine compartment. However, no significant main effect of prazosin treatment condition or interaction between prazosin and yohimbine-induced reinstatement was found. In all 15 mice were tested for the effect of $2 \mathrm{mg} / \mathrm{kg}$ prazosin on yohimbine-induced reinstatement (Figure 8b). Similar to the lower prazosin dose, two-way repeated-measures yohimbine $\times 2 \mathrm{mg} / \mathrm{kg}$ prazosin treatment condition ANOVA showed a significant overall effect of yohimbine $\left(F_{1,14}=\right.$ $11.558 ; p<0.01)$ on time spent in the cocaine compartment, with no main effect of prazosin treatment condition and no interaction between prazosin and yohimbine.

\section{Effects of Propranolol on Reinstatement}

To examine the role of $\beta$-ARs in reinstatement by various stimuli, mice were pretreated with the nonselective $\beta$-AR antagonist, propranolol, before FS or administration of cocaine or yohimbine. Propranolol blocked reinstatement by FS and yohimbine, but not cocaine. Further, FS-induced reinstatement was more sensitive to blockade by propranolol than yohimbine-induced reinstatement. 

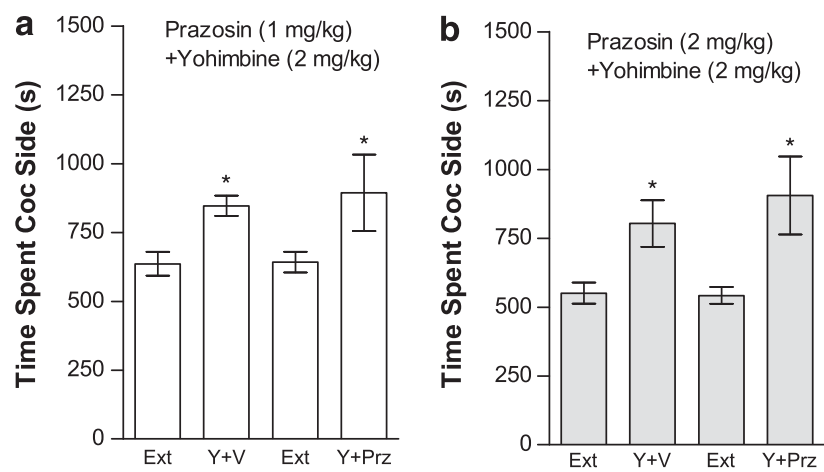

Figure 8 The selective $\alpha-\mid$ AR antagonist prazosin does not block yohimbine-induced reinstatement. Data represent the time spent in the cocaine (Coc) compartment (sec $\pm \mathrm{SE}$ ) during the final extinction session prior to reinstatement testing (Ext) and during reinstatement testing after administration of yohimbine ( $Y ; 2 \mathrm{mg} / \mathrm{kg}$, i.p.) after pretreatment with vehicle $(V)$ or $1 \mathrm{mg} / \mathrm{kg}$ (i.p.) prazosin (Prz; $n=6$; a) or pretreatment with $\vee$ or $2 \mathrm{mg} / \mathrm{kg}$ (i.p.) $\operatorname{Prz}(n=15 ; b)$. In both cases, significant main effects of $Y$ $(* p<0.05)$ but no $Y \times \operatorname{Prz}$ interactions were found.

\section{Forced Swim}

The effects of propranolol (5 or $10 \mathrm{mg} / \mathrm{kg}$, i.p.) on FSinduced reinstatement are shown in Figure 9. Both propranolol doses blocked FS-induced reinstatement. The effect of $5 \mathrm{mg} / \mathrm{kg}$ propranolol was tested in seven mice (Figure 9b). Two-way repeated-measures $\mathrm{FS} \times 5 \mathrm{mg} / \mathrm{kg}$ propranolol treatment condition ANOVA failed to show a significant overall effect of propranolol or FS on time spent in the cocaine compartment. However, a significant propranolol $\times$ FS interaction was observed $\left(F_{1,6}=8.598\right.$; $p<0.05)$. Post-hoc examination of reinstatement in each group revealed that FS significantly reinstated place preference in vehicle- but not $5 \mathrm{mg} / \mathrm{kg}$ propranolol-treated mice $\left(t_{6}=4.32 ; p<0.05\right)$. In all 16 mice were tested for the effects of $10 \mathrm{mg} / \mathrm{kg}$ propranolol on FS-induced reinstatement (Figure 9b). Two-way repeated-measures FS $\times 10 \mathrm{mg} / \mathrm{kg}$ propranolol treatment ANOVA showed a significant main effect of propranolol $\left(\mathrm{F}_{1,15}=7.018 ; p<0.05\right)$ but not $\mathrm{FS}$ and a significant interaction between $10 \mathrm{mg} / \mathrm{kg}$ propranolol treatment and FS $\left(\mathrm{F}_{1,15}=5.116 ; p<0.05\right)$. Post-hoc examination of reinstatement in each group revealed that FS significantly reinstated place preference in vehicle-treated but not $10 \mathrm{mg} / \mathrm{kg}$ propranolol-treated mice $\left(t_{15}=2.729\right.$; $p<0.05)$ and that time spent in the cocaine compartment was significantly reduced by propranolol after FS $\left(t_{15}=2.411 ; p<0.05\right)$ but not under basal conditions.

\section{Cocaine}

The effects of propranolol (5 or $10 \mathrm{mg} / \mathrm{kg}$, i.p.) on cocaineinduced reinstatement are shown in Figure 10. Neither propranolol dose blocked cocaine-induced reinstatement. The effect of $5 \mathrm{mg} / \mathrm{kg}$ propranolol was tested in nine mice (Figure 10a). Two-way cocaine $\times 5 \mathrm{mg} / \mathrm{kg}$ propranolol treatment condition ANOVA showed a significant overall effect of cocaine $\left(\mathrm{F}_{1,8}=9.731 ; p<0.05\right)$ on time spent in the cocaine compartment. However, no significant main effect of propranolol treatment condition or interaction between propranolol and cocaine-induced reinstatement was found.
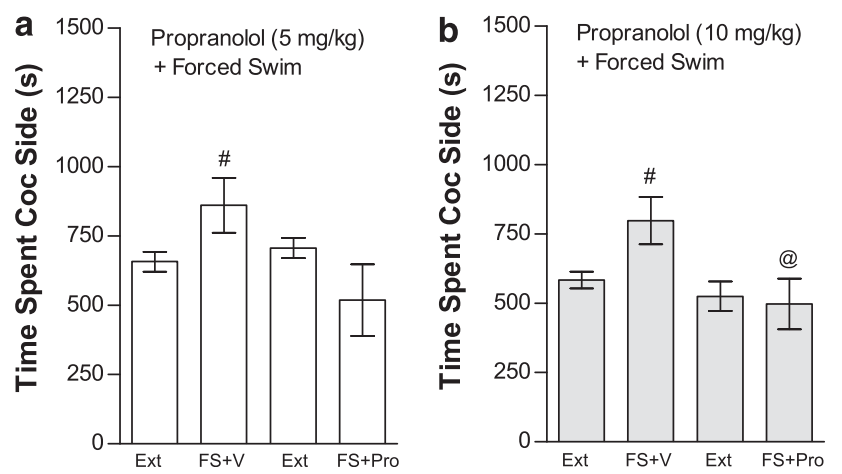

Figure 9 The nonselective $\beta$-AR antagonist propranolol blocks stressinduced reinstatement. Data represent the time spent in the cocaine (Coc) compartment (sec $\pm \mathrm{SE}$ ) during the final extinction session previous reinstatement testing (Ext) and during reinstatement testing after forced swim (FS) after pretreatment with vehicle (V) or propranolol (Pro). Significant interactions between FS and Pro were found in mice tested at the $5 \mathrm{mg} / \mathrm{kg}$ (i.p.; a; $n=7$ ) and $10 \mathrm{mg} / \mathrm{kg}$ (i.p.; b; $n=16$ ) Pro doses $(p<0.05)$. In each case, post-hoc testing showed that FS increased time spent in the Coc compartment after treatment with $\vee\left({ }^{\#} p<0.05\right)$ but not Pro. Further, time spent in the Coc compartment was significantly reduced following Pro compared to $V$ at the $10 \mathrm{mg} / \mathrm{kg}$, but not $5 \mathrm{mg} / \mathrm{kg}$, Pro dose $\left({ }^{(} p<0.05\right)$.
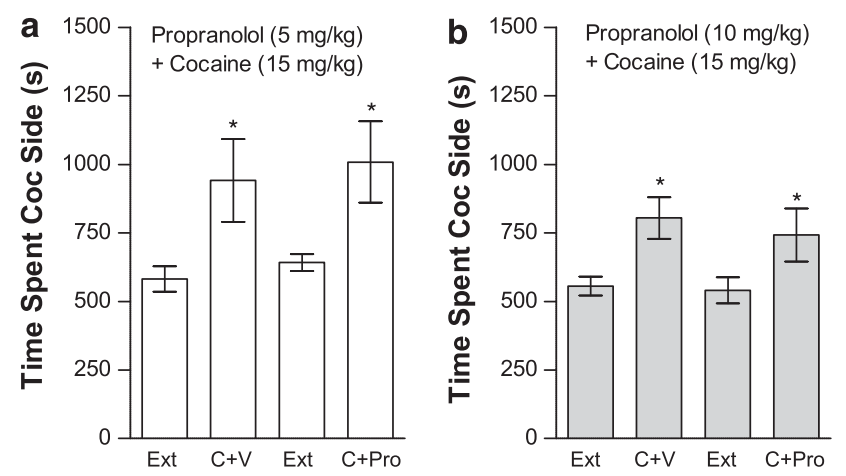

Figure 10 The non-selective $\beta-A R$ antagonist propranolol does not block cocaine-induced reinstatement. Data represent the time spent in the cocaine (Coc) compartment (sec $\pm \mathrm{SE}$ ) during the final extinction session before the reinstatement testing (Ext) and during reinstatement testing after administration of cocaine (C; $15 \mathrm{mg} / \mathrm{kg}$, i.p.) following pretreatment with vehicle (V) or $5 \mathrm{mg} / \mathrm{kg}$ (i.p.) propranolol (Pro; $n=9$; a) or pretreatment with $\vee$ or $10 \mathrm{mg} / \mathrm{kg}$ (i.p.) Pro $(n=11$; b). In both cases significant main effects of $C(* p<0.05)$ but no $C \times$ Pro interactions were found.

In all 11 mice were tested for the effect of $10 \mathrm{mg} / \mathrm{kg}$ propranolol on cocaine-induced reinstatement (Figure 10b). Similar to the lower propranolol dose, two-way cocaine $\times 10 \mathrm{mg} / \mathrm{kg}$ propranolol treatment condition ANOVA showed a significant overall effect of cocaine $\left(F_{1,10}=13.624\right.$; $p<0.01$ ) on time spent in the cocaine compartment, with no main effect of propranolol treatment condition and no interaction between propranolol treatment and cocaineinduced reinstatement.

\section{Yohimbine}

The effects of propranolol (5 or $10 \mathrm{mg} / \mathrm{kg}$, i.p.) on yohimbine-induced reinstatement are shown in Figure 11. Propranolol blocked yohimbine-induced reinstatement at 

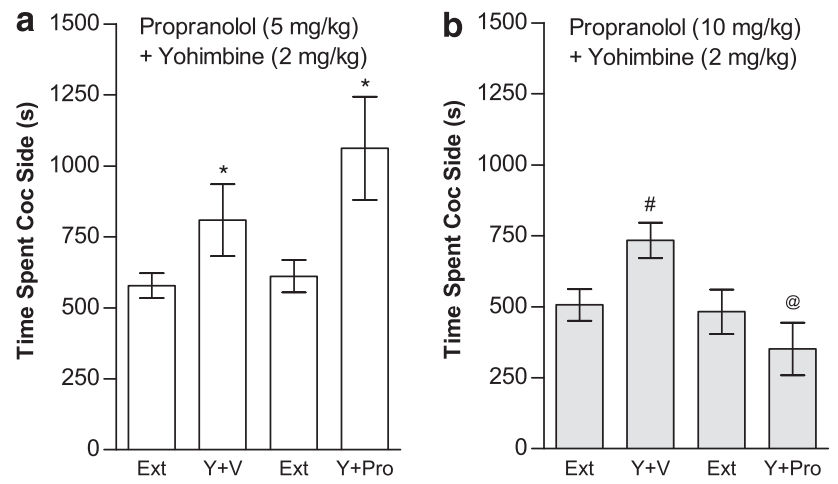

Figure II The nonselective $\beta$-AR antagonist propranolol dosedependently blocks yohimbine-induced reinstatement. Data in (a) represent the time spent in the cocaine (Coc) compartment (sec \pm SE) during the final extinction session before the reinstatement testing (Ext) and during reinstatement testing after administration of yohimbine ( $Y ; 2 \mathrm{mg} /$ $\mathrm{kg}$, i.p.) after pretreatment with vehicle $(\mathrm{V})$ or $5 \mathrm{mg} / \mathrm{kg}$ (i.p.) propranolol (Pro; $n=8)$. A significant main effect of $Y(* p<0.05)$ but no $Y \times$ Pro interaction was found at this dose. The effect of $10 \mathrm{mg} / \mathrm{kg}$ (i.p.) Pro $(n=10)$ on $Y$-induced reinstatement is shown in (b). A significant interaction between $Y$ and Pro was found at this dose $(p<0.05)$. Post-hoc testing showed that $Y$ increased time spent in the Coc compartment after treatment with $\vee\left({ }^{\#} p<0.05\right)$ but not $\mathrm{ICl}$. Further, time spent in the Coc compartment was significantly reduced following $10 \mathrm{mg} / \mathrm{kg}$ Pro compared to $\vee(@ p<0.05)$.

the $10 \mathrm{mg} / \mathrm{kg}$, but not at the $5 \mathrm{mg} / \mathrm{kg}$ dose. The effect of $5 \mathrm{mg} / \mathrm{kg}$ propranolol was tested in eight mice (Figure 11a). Two-way repeated-measures yohimbine $\times 5 \mathrm{mg} / \mathrm{kg}$ propranolol treatment condition ANOVA showed a significant overall effect of yohimbine $\left(\mathrm{F}_{1,7}=7.865 ; p<0.05\right)$ on time spent in the cocaine compartment. However, no significant main effect of $5 \mathrm{mg} / \mathrm{kg}$ propranolol treatment condition or interaction between $5 \mathrm{mg} / \mathrm{kg}$ propranolol and yohimbineinduced reinstatement was found. The effect of $10 \mathrm{mg} / \mathrm{kg}$ propranolol on yohimbine-induced reinstatement was tested in 10 mice (Figure 11b). In contrast to the lower propranolol dose, $10 \mathrm{mg} / \mathrm{kg}$ propranolol prevented reinstatement after yohimbine administration. Two-way repeated-measures yohimbine reinstatement $\times 10 \mathrm{mg} / \mathrm{kg}$ propranolol treatment condition ANOVA failed to show significant main effects of yohimbine or propranolol $(p=0.06)$ However, a significant interaction between $10 \mathrm{mg} / \mathrm{kg}$ propranolol treatment $\times$ yohimbine-induced reinstatement was found $\left(\mathrm{F}_{1,9}=10.563 ; p=0.01\right)$. Post-hoc analyses showed that yohimbine significantly increased the time spent in the cocaine compartment in vehicle-pretreated (paired $t$-test; two-tailed $t_{9}=2.334 ; p<0.05$ ) but not propranolol-pretreated mice, and that time spent in the cocaine compartment after yohimbine was significantly reduced in propranolol-pretreated mice compared with vehicle controls $\left(t_{9}=2.728 ; p<0.05\right)$.

\section{Effects of Betaxolol and ICI 118,551 on FS-Induced Reinstatement}

As FS-induced reinstatement seemed to involve $\beta$-AR but not $\alpha-1$ ARs, mice were tested with the $\beta-1$ AR selective receptor antagonist, betaxolol (10 mg/kg, i.p.), or the $\beta-2 \mathrm{AR}$ selective antagonist, ICI-118551 (5 mg/kg, i.p.), in order to determine the role of $\beta$ receptor subtypes in reinstatement
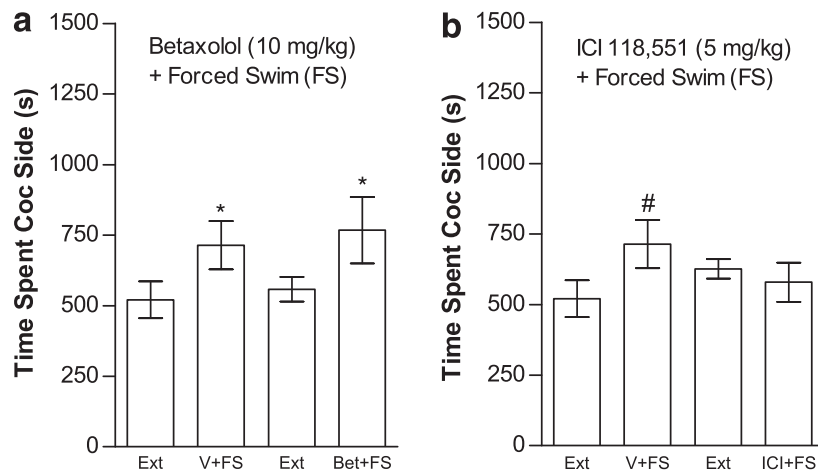

Figure I 2 The $\beta-2$ AR selective antagonist ICl- | |855| but not the $\beta$ - | $A R$ selective antagonist betaxolol blocks stress-induced reinstatement. Data in (a) represent the time spent in the cocaine (Coc) compartment (sec \pm SE) during the final extinction session prior to reinstatement testing (Ext) and during reinstatement testing after forced swim (FS) following pretreatment with vehicle $(V)$ or betaxolol (Bet; $10 \mathrm{mg} / \mathrm{kg}$, i.p.; $n=11$ ). A significant main effect of FS $(* p<0.05)$ but no FS $\times$ Bet interaction was found. The effect of $|\mathrm{Cl}-||855|(|\mathrm{Cl} ;| \mathrm{mg} / \mathrm{kg}$, i.p.; $n=\mid \mathrm{I})$ on FS-induced reinstatement is shown in (b). A significant interaction between $\mathrm{FS}$ and $\mathrm{ICl}$ was found $(p<0.05)$. Post-hoc testing showed that FS increased time spent in the cocaine compartment after treatment with $\vee\left({ }^{\#} p<0.05\right)$ but not $I C l$.

by FS (Figure 12). ICI-118551 (Figure 12b) but not betaxolol (Figure 12a) blocked FS-induced reinstatement. The effect of betaxolol was tested in 11 mice. Two-way repeatedmeasures ANOVA showed a significant main effect of FS on time spent in the cocaine compartment $\left(\mathrm{F}_{1,10}=9.762\right.$; $p<0.05$ ) but no effect of betaxolol or $\mathrm{FS} \times$ betaxolol reinstatement. In all, 11 mice were tested for the effect of ICI-118551 on FS-induced reinstatement. Two-way repeated-measures ANOVA showed no main effects of ICI118551 or FS on time spent in the cocaine compartment. However, a significant ICI-118551 $\times$ FS interaction was observed $\left(\mathrm{F}_{1,10}=9.364 ; p<0.05\right)$. Post-hoc analysis showed that FS produced significant reinstatement in vehicle, but not ICI-118551, treated mice $\left(t_{10}=2.874 ; p<0.05\right)$.

\section{DISCUSSION}

Drug re-exposure and stress are commonly cited as precipitating factors for relapse in recovering cocaine addicts. Although both stimuli can trigger drug use, they do not necessarily do so through activation of completely overlapping neurobiological pathways. The present study poses the noradrenergic system as a likely mediator of relapse in response to stressors but not cocaine. First, activation of central noradrenergic systems through disinhibition of noradrenergic signaling by administration of the $\alpha-2$ AR antagonist yohimbine or the more selective $\alpha-2 \mathrm{~A}$ AR antagonist BRL 44408 (Dwyer et al, 2010) is sufficient to induce reinstatement. Second, suppression of noradrenergic neurotransmission by the administration of the $\alpha-2$ AR agonist clonidine suppresses reinstatement by FS but not cocaine. Third, reinstatement by FS and yohimbine, but not cocaine, is blocked by the nonselective $\beta$-AR antagonist propranolol but not by the $\alpha-1 \mathrm{AR}$ antagonist, prazosin. In the case of FS, reinstatement is prevented by the selective $\beta-2$ AR antagonist ICI-118551, but not the selective $\beta-1$ AR antagonist, betaxolol. Altogether, these findings suggest that 
elevated norepinephrine (NE) during periods of stress, but not after cocaine re-exposure, likely induces drug seeking through activation of $\beta-2$ ARs as measured in this mouse model of relapse.

The apparent role for $\mathrm{NE}$ in stressor-induced relapse is also supported by previous studies. Icv NE administration reinstates cocaine seeking after SA (Brown et al, 2009), as does disinhibition of noradrenergic signaling through $\alpha-2$ adrenergic autoreceptor blockade (Lee et al, 2004; Feltenstein and See, 2006; Fletcher et al, 2008; Brown et al, 2009) and, in some cases, blockade of NE reuptake (Platt et al, 2007, but see Schmidt and Pierce, 2006). Conversely, suppression of stressor-induced NE release through administration of $\alpha-2$ AR agonists such as clonidine (Tjurmina et al, 1999) attenuates stress-induced drug seeking after SA of cocaine (Erb et al, 2000), heroin (Shaham et al, 2000a, b), alcohol (Le et al, 2005; Dzung Lê et al, 2009), or a heroincocaine mixture (Highfield et al, 2001) in rats, stressinduced reinstatement of morphine-induced place preference in rats (Wang et al, 2001) and drug craving induced by stress imagery in heroin-dependent human subjects (Sinha et al, 2007).

Although stress-induced reinstatement was blocked using propranolol and clonidine, these pretreatments failed to alter reinstatement in response to cocaine, even though clonidine has been shown to prevent cocaine-induced increases in brain extracellular NE levels (Florin et al, 1994). Considering that cocaine, like other NET blockers that have been shown to induce reinstatement (Platt et al, 2007), markedly elevates central NE levels (Reith et al, 1997; Li et al, 1996), and that elevation of central NE is sufficient to induce reinstatement (Brown et al, 2009), our findings suggest that cocaine-responsive processes activated either concurrently with or downstream from noradrenergic systems are sufficient for relapse in the absence of a NE response. This assertion is consistent with a number of reports suggesting that many neurobiological systems underlying stress-induced cocaine seeking (eg, CRF and $\kappa$-opioid) do not completely overlap with those underlying reinstatement in response to cocaine delivery (Erb et al, 1998; Shaham et al, 1998; Redila and Chavkin, 2008) and is supported by studies showing that suppression of noradrenergic neurotransmission through $\alpha-2$ AR activation (Erb et al, 2000) or antagonism of central $\beta$-ARs (Leri et al, 2002) blocks stress- but not cocaine-induced reinstatement in rats, as well as by findings that mixed $\alpha$ - and $\beta$-adrenergic receptor antagonist drugs do not attenuate the subjective responses to smoked cocaine, despite reducing peripheral adrenergic responses (Sofuoglu et al, $2000 \mathrm{a}, \mathrm{b})$. However, it should be noted that other studies have indicated that noradrenergic neurotransmission may be involved in cocaine-induced reinstatement in monkeys (Platt et al, 2007) and rats (Zhang and Kosten, 2005).

Our finding that propranolol blocks stressor-induced reinstatement is supported by those of Leri et al (2002), who found that administration of a combination of $\beta-1$ and $\beta-2$ AR antagonists directly into brain regions implicated in stressor-induced cocaine seeking blocks footshock-induced reinstatement after self-administration in rats. Propranolol has also been found to block reinstatement resulting from NET blockade after self-administration in monkeys (Platt et al, 2007). Further, as $\beta-A R$ are $G_{s}$ G-protein coupled receptors, the findings are consistent with a report that forced swim- but not cocaine-induced reinstatement of conditioned place preference is dependent on cAMP and CREB activation in mice (Kreibich and Blendy, 2004). Interestingly, $\beta$-blockers have been reported to attenuate anxiety-like effects resulting from cocaine delivery (Schank et al, 2008; elevated plus maze) or cocaine withdrawal (Harris and Aston-Jones, 1993; defensive burying). Thus, to the extent that these anxiogenic effects contribute to drug craving and relapse during withdrawal and/or continued cocaine use, our findings provide further evidence of potential utility of $\beta$-blockers for the management of cocaine addiction. Despite these findings, clinical trials examining the ability of propranolol to promote drug abstinence in cocaine-dependent individuals have found only modest improvement (Kampman et al, 2001, 2006) potentially because of the inability of propranolol to attenuate cocaine-induced craving and rewarding effects. Consistent with our own findings, it has been reported that propranolol fails to decrease cocaine-induced reinstatement in rats (Leri et al, 2002) and monkeys (Platt et al, 2007) and that drugs with $\beta$-AR antagonist properties fail to alter cocaine's subjective effects (Sofuoglu et al, 2000a, b). In fact, it has been reported that propranolol can actually augment cocaine's locomotor (Harris et al, 1996 but see Vanderschuren et al, 2003), discriminative stimulus (Kleven and Koek, 1997; but see Spealman, 1995), and reinforcing effects (Harris et al, 1996). It may be that, because of the selective attenuation of stress-induced cocaine seeking, targeting $\beta$-receptors may be more useful as an adjunct approach and/or only in subpopulations of cocaine-dependent individuals whose use is stress driven. In support, Kampman et al $(2001,2006)$ found that propranolol significantly increased abstinence time only in cocaine-dependent individuals experiencing pronounced withdrawal symptoms, which for cocaine dependence include intense anxiety (Gawin and Kleber, 1986).

In the present study, stressor-induced reinstatement seemed to involve $\beta-2 \mathrm{AR}$, presumably within the CNS, but not $\beta-1$ AR. FS-induced reinstatement was blocked by the selective $\beta-2$ AR antagonist ICI-118551 but not the $\beta-1$ AR antagonist betaxolol. This finding was somewhat surprising, considering that it has been previously reported that betaxolol blocked anxiety-like behavior during withdrawal from chronic cocaine administration (Rudoy and Van Bockstaele, 2007). The role of $\beta-2$ AR in stress- and anxiety-related processes is unclear. However, $\beta-2$ AR are found throughout the rat brain, including in the BNST (Rainbow et al, 1985) and the amygdala (Tiong and Richardson, 1990), sites in which nonselective antagonism of $\beta$-AR has been shown to attenuate stressor-induced cocaine seeking (Leri et al, 2002) and in which $\beta-2$ AR have been implicated in affective, but not sensory or somatic, elements of pain (Deyama et al, 2008) or opiate withdrawal (Watanabe et al, 2003). Confirmation that central but not peripheral $\beta-2$ AR activation is required for stress-induced reinstatement will require further investigation.

In contrast to propranolol, the $\alpha-1$ AR antagonist prazosin ( 1 or $2 \mathrm{mg} / \mathrm{kg}$ ) failed to alter reinstatement by any of the stimuli tested. The finding that prazosin did not alter cocaine-induced reinstatement was somewhat surprising considering that prazosin has been reported to attenuate 
cocaine-induced reinstatement after self-administration in rats (Zhang and Kosten, 2005) but not monkeys (Platt et al, 2007). This disparity in prazosin effects on cocaine-evoked reinstatement across studies could be attributable to a number of factors, including species, general approach/ experimental parameters, and dose. A role for $\alpha-1$ ARs in a number of cocaine effects has been identified, including cocaine's reinforcing (Drouin et al, 2002; Wee et al, 2008 but see Woolverton, 1987), sensitizing (Jiménez-Rivera et al, 2006; Zhang and Kosten, 2007), locomotor stimulating (Drouin et al, 2002; Snoddy and Tessel, 1985 but see Vanderschuren et al, 2003), and discriminative stimulus (Spealman, 1995) effects.

Our finding that yohimbine administration reinstates extinguished place preference in mice is consistent with previous reports that yohimbine reinstates extinguished cocaine seeking after SA in rats (Feltenstein and See, 2006; Fletcher et al, 2008; Brown et al, 2009) and monkeys (Lee et al, 2004) and impairs the extinction of cocaine-induce conditioned place preference in mice (Davis et al, 2008). As we were able to block yohimbine-induced reinstatement with propranolol, we presumed that yohimbine's effects on cocaine seeking were attributable to disinhibition of noradrenergic activity resulting from antagonism of $\alpha-2$ adrenergic autoreceptors. Consistent with this, it has been reported that the highly selective $\alpha-2$ adrenergic receptor antagonist RS-79948 can induce reinstatement in monkeys (Lee et al, 2004) and that RS-79948- and yohimbine-induced reinstatement are blocked by the $\alpha-2$ adrenergic receptor agonist, clonidine (Lee et al, 2004). A similar clonidineinhibited $\beta$-AR-dependent mechanism has been reported to be involved in the reinstatement of extinguished cocaine seeking by the selective NET inhibitor, nisoxetine in squirrel monkeys (Platt et al, 2007). Surprisingly however, in the present study, clonidine failed to block yohimbineinduced reinstatement. These findings are consistent with a recent report that clonidine failed to prevent yohimbineinduced reinstatement of cocaine seeking after SA in rats (Brown et al, 2009).

It is unclear why clonidine is ineffective in blocking yohimbine-induced reinstatement of cocaine seeking. However, there are two possibilities. First, yohimbine could be inducing reinstatement through a non- $\alpha-2$ AR mechanism. In support, Davis et al (2008) reported that the impairment of extinction of cocaine-induced conditioned place preference and suppression of glutamate-induced electrophysiological responses in brain slices containing the bed nucleus of the stria terminalis by yohimbine were unaltered in $\alpha-2 \mathrm{~A}$ adrenergic receptor deficient mice and were not mimicked by the more selective $\alpha-2 \mathrm{~A}$ AR antagonist, atipamezole. Yohimbine has been reported to function as an agonist at 5- $\mathrm{HT}_{1 \mathrm{~A}}$ receptors (Winter and Rabin, 1992; Millan et al, 2000). This $5-\mathrm{HT}_{1 \mathrm{~A}}$ receptor agonist effect may be relevant to drug seeking, as yohimbine-induced reinstatement of extinguished alcohol seeking in rats is attenuated by the $5-\mathrm{HT}_{1 \mathrm{~A}}$ receptor antagonist, WAY 100635 , as well as clonidine, but is minimally reduced by lesions of ascending noradrenergic systems (Dzung Lê et al, 2009). To further examine the role for $\alpha-2$ AR antagonism in reinstatement, we also tested mice with the selective $\alpha-2 \mathrm{~A}$ antagonist BRL 44408, a compound that has a 50-fold higher affinity for $\alpha-2 \mathrm{~A}$ AR relative to 5 -HT-1A receptors (Dwyer et al, 2010). Like yohimbine, this more selective $\alpha-2 \mathrm{~A} \mathrm{AR}$ antagonist also produced robust reinstatement, suggesting that $\alpha-2$ AR antagonism alone is likely sufficient for reinstatement. Notably, if indeed yohimbine is working through a mechanism that is independent of $\alpha-2 \mathrm{AR}$, our data suggest that this mechanism still involves $\beta$-AR.

Secondly, clonidine itself is somewhat nonselective. Lower clonidine doses likely primarily target presynaptic $\alpha-2$ ARs, thereby competitively reversing yohimbine effects and generally suppressing noradrenergic neurotransmission through $\alpha$-2 AR-mediated auto-inhibitory actions. Accordingly, at the lower (ie, $0.03 \mathrm{mg} / \mathrm{kg}$ ) dose, clonidine prevented reinstatement by FS. In addition to attenuating NE release, higher clonidine doses also activate lower affinity postsynaptic $\alpha-2$ ARs and/or bind to imidazoline I1 receptor sites (Bricca et al, 1989; Eglen et al, 1998), thus mimicking components of the noradrenergic response despite indirectly reducing activation of $\alpha-1$ and $\beta$-AR or producing nonnoradrenergic effects. On the basis of our finding that the higher (ie, $0.3 \mathrm{mg} / \mathrm{kg}$ ) clonidine dose not only failed to attenuate yohimbine and FS-induced reinstatement but induced reinstatement on its own, we hypothesize that, similar to $\beta-\mathrm{AR}$, these high-dose targets may contribute to reinstatement during stress. This finding is consistent with another report that high doses of clonidine can induce conditioned place preference in rats (Cervo et al, 1993). Future studies using putative imidazoline receptor ligands as well as other $\alpha-2 \mathrm{AR}$ agonists with relatively low affinity for imidazoline receptors (eg, guanabenz) are needed to determine the relative contribution of these receptor populations to reinstatement. Overall, this dose-dependent regulation of differential receptor populations with varying effects on drug seeking, along with the tendency of yohimbine to interact with multiple receptor targets, likely contributed to the observed variation in clonidine's ability to block yohimbine-induced reinstatement in this study and others.

NE-dependent stress-induced reinstatement seems to involve projections from the lateral tegmental region of the brainstem to the bed nucleus of the stria terminalis (BNST) and/or the central nucleus of the amygdala (CeA) by the ventral noradrenergic bundle and activation $\beta$-ARs. In rats, stress- but not drug-induced reinstatement is attenuated by administration of clonidine into the lateral tegmentum, but not the LC (Shaham et al, 2000a, b; heroin) or into the BNST (Wang et al, 2001; cocaine) or by delivery of a combination of $\beta-1$ and $\beta-2$ adrenergic receptor antagonists into the $\mathrm{BNST}$ or CeA (Leri et al, 2002; cocaine). It has been postulated that NE released into these regions regulates the release of corticotropin releasing factor (CRF) which in turn can indirectly (by actions in the BNST; Erb et al, 2001) or directly (by actions in the ventral tegmental area; Wang et al, 2005) activate mesocorticolimbic activity, thus producing drug-seeking behavior. The apparent lack of involvement of CRF (Shaham et al, 1998; Erb et al, 1998) and NE (Erb et al, 2000, Leri et al, 2002, and present findings; but see Platt et al, 2007, Zhang and Kosten, 2005) in cocaine-induced reinstatement suggests that despite convergence within the mesocorticolimbic system, the neurobiological pathways underlying drug and stress induced relapse are largely distinct. 
$\beta$-AR, specifically $\beta-2 \mathrm{AR}$, have also been implicated in the post-retrieval reconsolidation of cocaine-induced conditioned place preference in mice. Systemic propranolol (Bernardi et al, 2006; Fricks-Gleason and Marshall, 2008) and intrabasolateral amygdalar ICI-118551 (Bernardi et al, 2009) injections interfere specifically with the reconsolidation of conditioned place preference after retrieval without enhancing extinction learning. As, in our study, mice did not receive propranolol or ICI-118551 until after place preference had already been extinguished and as drug administration occurred immediately before to exposure of the reinstating stimuli, it is unlikely that effects on reconsolidation contributed to the observed attenuation of reinstatement. Nonetheless, the potential ability of $\beta-2$ AR antagonists to attenuate stress-evoked relapse and interfere with reconsolidation of drug-associated memories, establishes $\beta-2$ ARs as a target of interest for the treatment of addiction.

In summary, these findings further suggest that central noradrenergic systems contribute to drug-seeking behavior during times of stress. Considering that repeated cocaine exposure is associated with progressive changes in brain noradrenergic systems (Belej et al, 1996; Macey et al, 2003; Baumann et al, 2004; Beveridge et al, 2005; Horne et al, 2008; Lanteri et al, 2008) and that early abstinence from cocaine in dependent individuals is associated with an exaggerated noradrenergic response (McDougle et al, 1994), targeting noradrenergic neurotransmission, particularly $\beta-2$ AR, may be particularly beneficial for the management of relapse in cocaine-dependent individuals whose drug use is stress-related.

\section{ACKNOWLEDGEMENTS}

This work was supported by the National Institute on Drug Abuse (NIDA) grant numbers DA15758 and DA025617. We thank Ms Amanda Clifford for her work in helping to establish the mouse conditioned place preference protocol.

\section{DISCLOSURE}

The authors declare no conflict of interest. The authors have received financial support or compensation as follows: John $\mathrm{R}$ Mantsch is a Founder and past Director of as well as a consultant for and stockholder in Promentis Pharmaceuticals and has served as a consultant for WIL Research (Ashland, $\mathrm{OH}$ ). He has received research support from the $\mathrm{NIH}$ and the State of Wisconsin Biotechnology Alliance. He is a full-time employee of Marquette University. David A Baker is a Founder and Director of as well as a consultant for and stockholder in Promentis Pharmaceuticals. He has received research support from the $\mathrm{NIH}$, the State of Wisconsin Biotechnology Alliance, and the National Alliance for Research on Schizophrenia and Addiction. He is a full-time employee of Marquette University. Chad E Beyer was a full-time employee of Wyeth Pharmaceuticals (Princeton, NJ) at the time that these studies were completed. Holly Caretta, Andy Weyer, and Oliver Vranjkovic were employees of Marquette University at the time that these studies were completed.

\section{REFERENCES}

Abercrombie ED, Keller Jr RW, Zigmond MJ (1988). Characterization of hippocampal norepinephrine release as measured by microdialysis perfusion: pharmacological and behavioral studies. Neuroscience 27: 897-904.

Baumann MH, Milchanowski AB, Rothman RB (2004). Evidence for alterations in alpha2-adrenergic receptor sensitivity in rats exposed to repeated cocaine administration. Neuroscience 125: 683-690.

Belej T, Manji D, Sioutis S, Barros HM, Nobrega JN (1996). Changes in serotonin and norepinephrine uptake sites after chronic cocaine: pre- vs. post-withdrawal effects. Brain Res 736: 287-296.

Bernardi RE, Lattal KM, Berger SP (2006). Postretrieval propranolol disrupts a cocaine conditioned place preference. Neuroreport 17: 1443-1447.

Bernardi RE, Ryabinin AE, Berger SP, Lattal KM (2009). Post-retrieval disruption of a cocaine conditioned place preference by systemic and intrabasolateral amygdala beta2and alpha1-adrenergic antagonists. Learn Mem 16: 777-789.

Beveridge TJ, Smith HR, Nader MA, Porrino LJ (2005). Effects of chronic cocaine self-administration on norepinephrine transporters in the nonhuman primate brain. Psychopharmacology 180: 781-788.

Bricca G, Dontenwill M, Molines A, Feldman J, Belcourt A, Bousquet $P$ (1989). The imidazoline preferring receptor: binding studies in bovine, rat and human brainstem. Eur J Pharmacol 162: 1-9.

Brown ZJ, Tribe E, D'souza NA, Erb S (2009). Interaction between noradrenaline and corticotrophin-releasing factor in the reinstatement of cocaine seeking in the rat. Psychopharmacology 203: $121-130$.

Cervo L, Rossi C, Samanin R (1993). Clonidine-induced place preference is mediated by alpha 2 -adrenoceptors outside the locus coeruleus. Eur J Pharmacol 238: 201-207.

Davis AR, Shields AD, Brigman JL, Norcross M, McElligott ZA, Holmes A et al (2008). Yohimbine impairs extinction of cocaine-conditioned place preference in an alpha- 2 adrenergic receptor independent process. Learn Mem 26: 667-676.

Deyama S, Katayama T, Ohno A, Nakagawa T, Kaneko S, Yamaguchi $\mathrm{T}$ et al (2008). Activation of the beta-adrenoceptorprotein kinase A signaling pathway within the ventral bed nucleus of the stria terminalis mediates the negative affective component of pain in rats. J Neurosci 28: 7728-7736.

Drouin C, Darracq L, Trovero F, Blanc G, Glowinski J, Cotecchia S et al (2002). Alpha1b-adrenergic receptors control locomotor and rewarding effects of psychostimulants and opiates. J Neurosci 22: 2873-2884.

Dwyer JM, Platt BJ, Sukoff Rizzo SJ, Pulicicchio CM, Wantuch C, Zhang MY et al (2010). Preclinical characterization of BRL 44408: antidepressant- and analgesic-like activity through selective alpha2A-adrenoceptor antagonism. Int J Neuropsychopharmacol 5: 1-13.

Dzung Lê A, Funk D, Harding S, Juzytsch W, Fletcher PJ (2009). The role of noradrenaline and 5-hydroxytryptamine in yohimbine-induced increases in alcohol-seeking in rats. Psychopharmacology 204: 477-488.

Eglen RM, Hudson AL, Kendall DA, Nutt DJ, Morgan NG, Wilson VG et al (1998). Seeing through a glass darkly': casting light on imidazoline 'I' sites. Trends Pharmacol Sci 19: 381-390.

Erb S, Shaham Y, Stewart J (1998). The role of corticotropinreleasing factor and corticosterone in stress- and cocaine-induced relapse to cocaine seeking in rats. $J$ Neurosci 18: 5529-5536.

Erb S, Hitchcott PK, Rajabi H, Mueller D, Shaham Y, Stewart J (2000). Alpha-2 adrenergic receptor agonists block 
stress-induced reinstatement of cocaine seeking. Neuropsychopharmacology 23: 138-150.

Erb S, Salmaso N, Rodaros D, Stewart J (2001). A role for the CRFcontaining pathway from central nucleus of the amygdala to bed nucleus of the stria terminalis in the stress-induced reinstatement of cocaine seeking in rats. Psychopharmacology 158: 360-365.

Feltenstein MW, See RE (2006). Potentiation of cue-induced reinstatement of cocaine-seeking in rats by the anxiogenic drug yohimbine. Behav Brain Res 174: 1-8.

Finlay JM, Zigmond MJ, Abercrombie ED (1995). Increased dopamine and norepinephrine release in the medial prefrontal cortex induced by acute and chronic stress: effects of diazepam. Neuroscience 64: 619-628.

Fletcher PJ, Rizos Z, Sinyard J, Tampakeras M, Higgins GA (2008). The 5-HT2C receptor agonist Ro60-0175 reduces cocaine selfadministration and reinstatement induced by the stressor yohimbine, and contextual cues. Neuropsychopharmacology 33: 1402-1412.

Florin SM, Kuczenski R, Segal DS (1994). Regional extracellular norepinephrine responses to amphetamine and cocaine and effects of clonidine pretreatment. Brain Res 654: 53-62.

Fricks-Gleason AN, Marshall JF (2008). Post-retrieval betaadrenergic receptor blockade: effects on extinction and reconsolidation of cocaine-cue memories. Learn Mem 15: 643-648.

Gawin FH, Kleber HD (1986). Abstinence symptomatology and psychiatric diagnosis in cocaine abusers. Clinical observations. Arch Gen Psychiatry 43: 107-113.

Harris GC, Aston-Jones G (1993). Beta-adrenergic antagonists attenuate withdrawal anxiety in cocaine- and morphine-dependent rats. Psychopharmacology 113: 131-136.

Harris GC, Hedaya MA, Pan W-J, Kalivas P (1996). Beta-adrenergic antagonism alters the behavioral and neurochemical responses to cocaine. Neuropsychopharmacology 14: 195-204.

Highfield D, Yap J, Grimm JW, Shalev U, Shaham Y (2001). Repeated lofexidine treatment attenuates stress-induced, but not drug cues-induced reinstatement of a heroin-cocaine mixture (speedball) seeking in rats. Neuropsychopharmacology 25: 320331.

Horne MK, Lee J, Chen F, Lanning K, Tomas D, Lawrence AJ (2008). Long-term administration of cocaine or serotonin reuptake inhibitors results in anatomical and neurochemical changes in noradrenergic, dopaminergic, and serotonin pathways. J Neurochem 106: 1731-1744.

Itzhak Y, Martin JL (2002). Cocaine-induced conditioned place preference in mice: induction, extinction and reinstatement by related psychostimulants. Neuropsychopharmacology 26: $130-134$.

Jiménez-Rivera CA, Feliu-Mojer M, Vázquez-Torres R (2006). Alpha-noradrenergic receptors modulate the development and expression of cocaine sensitization. Ann NY Acad Sci 1074: 390-402.

Kampman KM, Volpicelli JR, Mulvaney F, Alterman AI, Cornish J, Gariti P et al (2001). Effectiveness of propranolol for cocaine dependence treatment may depend on cocaine withdrawal symptom severity. Drug Alcohol Depend 63: 69-78.

Kampman KM, Dackis C, Lynch KG, Pettinati H, Tirado C, Gariti P et al (2006). A double-blind, placebo-controlled trial of amantadine, propranolol, and their combination for the treatment of cocaine dependence in patients with severe cocaine withdrawal symptoms. Drug Alcohol Depend 85: 129-137.

Kleven MS, Koek W (1997). Discriminative stimulus properties of cocaine: enhancement by beta-adrenergic receptor antagonists. Psychopharmacology 131: 307-312.

Kreibich AS, Blendy JA (2004). cAMP response element-binding protein is required for stress but not cocaine-induced reinstatement. J Neurosci 24: 6686-6692.

Lanteri C, Salomon L, Torrens Y, Glowinski J, Tassin JP (2008). Drugs of abuse specifically sensitize noradrenergic and serotonergic neurons via a non-dopaminergic mechanism. Neuropsychopharmacology 33: 1724-1734.

Le AD, Harding S, Juzytsch W, Funk D, Shaham Y (2005). Role of alpha-2 adrenoceptors in stress-induced reinstatement of alcohol seeking and alcohol self-administration in rats. Psychopharmacology 179: 366-373.

Lee B, Tiefenbacher S, Platt DM, Spealman RD (2004). Pharmacological blockade of alpha2-adrenoceptors induces reinstatement of cocaine-seeking behavior in squirrel monkeys. Neuropsychopharmacology 29: 686-693.

Leri F, Flores J, Rodaros D, Stewart J (2002). Blockade of stressinduced but not cocaine-induced reinstatement by infusion of noradrenergic antagonists into the bed nucleus of the stria terminalis or the central nucleus of the amygdala. J Neurosci 22: 5713-5718.

Li MY, Yan QS, Coffey LL, Reith ME (1996). Extracellular dopamine, norepinephrine, and serotonin in the nucleus accumbens of freely moving rats during intracerebral dialysis with cocaine and other monoamine uptake blockers. $J$ Neurochem 66: 559-568.

Lu L, Shepard JD, Scott Hall F, Shaham Y (2003). Effect of environmental stressors on opiate and psychostimulant reinforcement, reinstatement and discrimination in rats: a review. Neurosci Biobehav Rev 27: 457-491.

Macey DJ, Smith HR, Nader MA, Porrino LJ (2003). Chronic cocaine self-administration upregulates the norepinephrine transporter and alters functional activity in the bed nucleus of the stria terminalis of the rhesus monkey. J Neurosci 23: 12-16. McDougle CJ, Black JE, Malison RT, Zimmermann RC, Kosten TR, Heninger GR et al (1994). Noradrenergic dysregulation during discontinuation of cocaine use in addicts. Arch Gen Psychiatry 51: 713-719.

Millan MJ, Newman-Tancredi A, Audinot V, Cussac D, Lejeune F, Nicolas JP et al (2000). Agonist and antagonist actions of yohimbine as compared to fluparoxan at alpha(2)-adrenergic receptors (AR)s, serotonin (5-HT)(1A), 5-HT(1B), 5-HT(1D) and dopamine $D(2)$ and $D(3)$ receptors. Significance for the modulation of frontocortical monoaminergic transmission and depressive states. Synapse 35: 79-95.

Orsini C, Bonito-Oliva A, Conversi D, Cabib S (2008). Genetic liability increases propensity to prime-induced reinstatement of conditioned place preference in mice exposed to low cocaine. Psychopharmacology 198: 287-296.

Platt DM, Rowlett JK, Spealman RD (2007). Noradrenergic mechanisms in cocaine-induced reinstatement of drug seeking in squirrel monkeys. J Pharmacol Exp Ther 322: 894-902.

Rainbow TC, Parsons B, Wolfe BB (1985). Quantitative autoradiography of beta 1 - and beta 2 -adrenergic receptors in rat brain. Proc Natl Acad Sci, USA 81: 1585-1589.

Redila VA, Chavkin C (2008). Stress-induced reinstatement of cocaine seeking is mediated by the kappa opioid system. Psychopharmacology 200: 59-70.

Reith ME, Li MY, Yan QS (1997). Extracellular dopamine, norepinephrine, and serotonin in the ventral tegmental area and nucleus accumbens of freely moving rats during intracerebral dialysis following systemic administration of cocaine and other uptake blockers. Psychopharmacology 134: 309-317.

Ribeiro Do Couto B, Aguilar MA, Manzanedo C, Rodríguez-Arias M, Armario A, Miñarro J (2006). Social stress is as effective as physical stress in reinstating morphine-induced place preference in mice. Psychopharmacology 185: 459-470.

Rudoy CA, Van Bockstaele EJ (2007). Betaxolol, a selective beta(1)adrenergic receptor antagonist, diminishes anxiety-like behavior during early withdrawal from chronic cocaine administration in rats. Prog Neuropsychopharmacol Biol Psychiatry 31: 1119-1129.

Sanger DJ, Schoemaker H (1992). Discriminative stimulus properties of 8-OH-DPAT: relationship to affinity for 5HT1A receptors. Psychopharmacology 108: 85-92. 
Schank JR, Liles LC, Weinshenker D (2008). Norepinephrine signaling through beta-adrenergic receptors is critical for expression of cocaine-induced anxiety. Biol Psychiatry 63: 1007-1012.

Schmidt HD, Pierce RC (2006). Systemic administration of a dopamine, but not a serotonin or norepinephrine, transporter inhibitor reinstates cocaine seeking in the rat. Behav Brain Res 175: $189-194$.

Shaham Y, Erb S, Leung S, Buczek Y, Stewart J (1998). CP-154,526, a selective, non-peptide antagonist of the corticotropin-releasing factor1 receptor attenuates stress-induced relapse to drug seeking in cocaine- and heroin-trained rats. Psychopharmacology 137: 184-190.

Shaham Y, Highfield D, Delfs J, Leung S, Stewart J (2000a). Clonidine blocks stress-induced reinstatement of heroin seeking in rats: an effect independent of locus coeruleus noradrenergic neurons. Eur J Neurosci 12: 292-302.

Shaham Y, Erb S, Stewart J (2000b). Stress-induced relapse to heroin and cocaine seeking in rats: a review. Brain Res Brain Res Rev 33: 13-33.

Shaham Y, Shalev U, Lu L, De Wit H, Stewart J (2003). The reinstatement model of drug relapse: history, methodology and major findings. Psychopharmacology 168: 3-20.

Sinha R (2001). How does stress increase risk of drug abuse and relapse? Psychopharmacology 158: 343-359.

Sinha R, Talih M, Malison R, Cooney N, Anderson GM, Kreek MJ (2003). Hypothalamic-pituitary-adrenal axis and sympathoadreno-medullary responses during stress-induced and drug cue-induced cocaine craving states. Psychopharmacology 170: $62-72$.

Sinha R, Kimmerling A, Doebrick C, Kosten TR (2007). Effects of lofexidine on stress-induced and cue-induced opioid craving and opioid abstinence rates: preliminary findings. Psychopharmacology 190: 569-574.

Smith RJ, Aston-Jones G (2008). Noradrenergic transmission in the extended amygdala: role in increased drug-seeking and relapse during protracted abstinence. Brain Struct Funct 213: 43-61.

Snoddy AM, Tessel RE (1985). Prazosin: effect on psychomotorstimulant cues and locomotor activity in mice. Eur J Pharmacol 116: $221-228$.

Sofuoglu M, Brown S, Babb DA, Pentel PR, Hatsukami DK (2000a). Effects of labetalol treatment on the physiological and subjective response to smoked cocaine. Pharmacol Biochem Behav 65: 255-259.

Sofuoglu M, Brown S, Babb DA, Pentel PR, Hatsukami DK (2000b). Carvedilol affects the physiological and behavioral response to smoked cocaine in humans. Drug Alcohol Depend 60: 69-76.

Sofuoglu M, Sewell RA (2009). Norepinephrine and stimulant addiction. Addict Biol 14: 119-129.

Spealman RD (1995). Noradrenergic involvement in the discriminative stimulus effects of cocaine in squirrel monkeys. J Pharmacol Exp Ther 275: 53-62.
Stewart J (2003). Stress and relapse to drug seeking: studies in laboratory animals shed light on mechanisms and sources of long-term vulnerability. Am J Addict 12: 1-17.

Tanaka T, Yokoo H, Mizoguchi K, Yoshida M, Tsuda A, Tanaka M (1991). Noradrenaline release in the rat amygdala is increased by stress: studies with intracerebral microdialysis. Brain Res 544: 174-176.

Tiong AH, Richardson JS (1990). The characterization of beta adrenoceptor subtypes in the rat amygdala and hippocampus. Int J Neurosci 54: 231-244.

Tjurmina OA, Goldstein DS, Palkovits M, Kopin IJ (1999). Alpha-2 adrenoceptor-mediated restraint of norepinephrine synthesis, release, and turnover during immobilization in rats. Brain Res 826: $243-252$.

Tzschentke TM (2007). Measuring reward with the conditioned place preference (CPP) paradigm: update of the last decade. Addict Biol 12: 227-462.

Vanderschuren LJ, Beemster P, Schoffelmeer AN (2003). On the role of noradrenaline in psychostimulant-induced psychomotor activity and sensitization. Psychopharmacol 169: 176-185.

Wang B, Shaham Y, Zitzman D, Azari S, Wise RA, You ZB (2005). Cocaine experience establishes control of midbrain glutamate and dopamine by corticotropin-releasing factor: a role in stressinduced relapse to drug seeking. J Neurosci 25: 5389-5396.

Wang X, Cen X, Lu L (2001). Noradrenaline in the bed nucleus of the stria terminalis is critical for stress-induced reactivation of morphine-conditioned place preference in rats. Eur J Pharmacol 432: $153-161$.

Watanabe T, Nakagawa T, Yamamoto R, Maeda A, Minami M, Satoh M (2003). Involvement of noradrenergic system within the central nucleus of the amygdala in naloxone-precipitated morphine withdrawal-induced conditioned place aversion in rats. Psychopharmacology 170: 80-88.

Wee S, Mandyam CD, Lekic DM, Koob GF (2008). Alpha 1noradrenergic system role in increased motivation for cocaine intake in rats with prolonged access. Eur Neuropsychopharmacol 18: 303-311.

Weinshenker D, Schroeder JP (2007). There and back again: a tale of norepinephrine and drug addiction. Neuropsychopharmacology 32: 1433-1451.

Winter JC, Rabin RA (1992). Yohimbine as a serotonergic agent: evidence from receptor binding and drug discrimination. J Pharmacol Exp Ther 263: 682-689.

Woolverton WL (1987). Evaluation of the role of norepinephrine in the reinforcing effects of psychomotor stimulants in rhesus monkeys. Pharmacol Biochem Behav 26: 835-839.

Zhang XY, Kosten TA (2005). Prazosin, an alpha-1 adrenergic antagonist, reduces cocaine-induced reinstatement of drugseeking. Biol Psychiatry 57: 1202-1204.

Zhang XY, Kosten TA (2007). Previous exposure to cocaine enhances cocaine self-administration in an alpha 1-adrenergic receptor dependent manner. Neuropsychopharmacology 32: 638-645. 